Prepared in cooperation with the City of Wichita, Kansas

\title{
Groundwater-Level and Storage-Volume Changes in the Equus Beds Aquifer near Wichita, Kansas, Predevelopment through January 2015
}

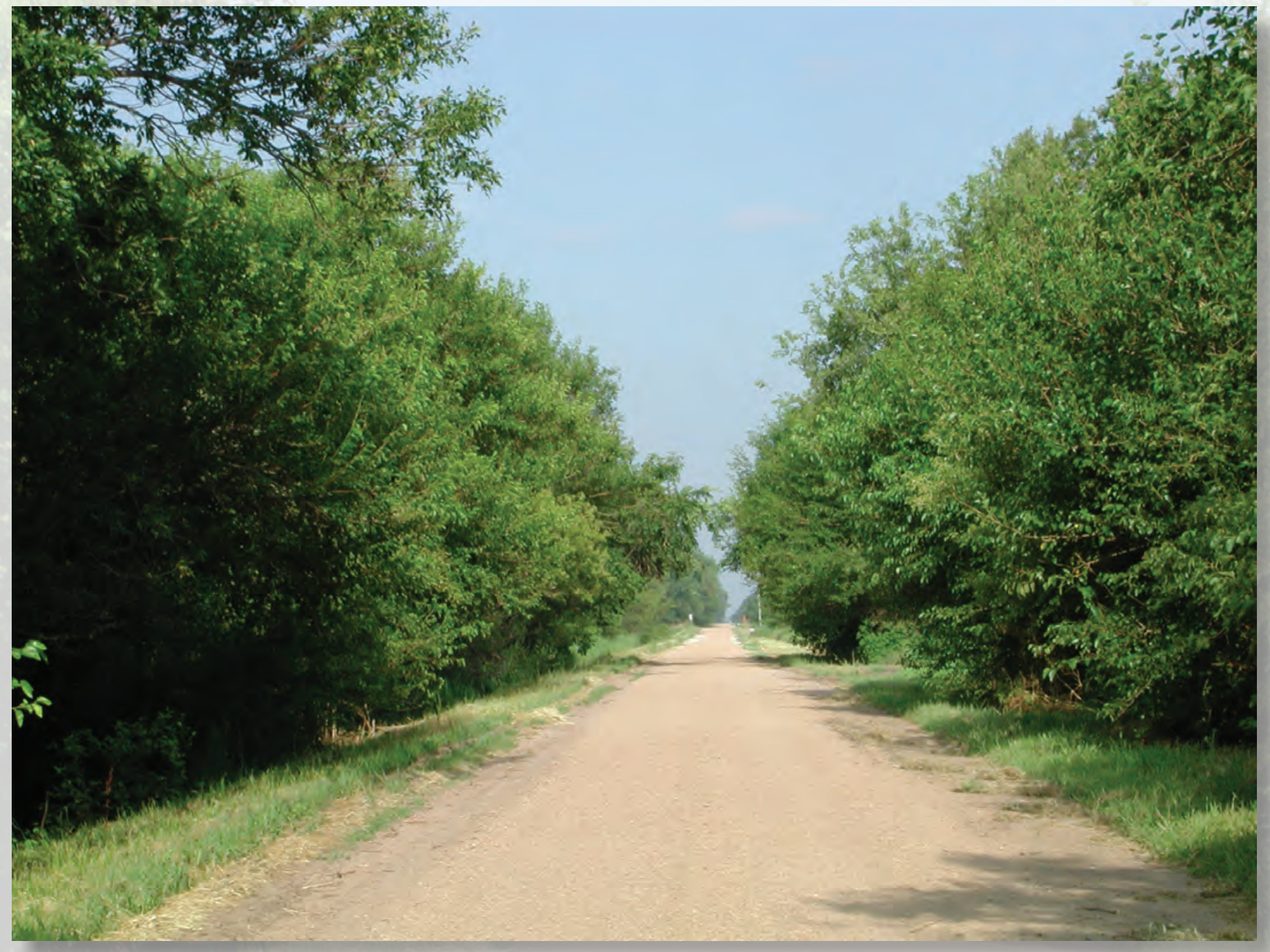

Scientific Investigations Report 2015-5121 
Cover. Well cluster IW-25, looking west, 2006. Photograph by Trudy Bennett, U.S. Geological Survey. 


\section{Groundwater-Level and Storage-Volume Changes in the Equus Beds Aquifer near Wichita, Kansas, Predevelopment through January 2015}

By Joshua A. Whisnant, Cristi V. Hansen, and Patrick J. Eslick

Prepared in cooperation with the City of Wichita, Kansas

Scientific Investigations Report 2015-5121 


\title{
U.S. Department of the Interior SALLY JEWELL, Secretary
}

\section{U.S. Geological Survey \\ Suzette M. Kimball, Acting Director}

\author{
U.S. Geological Survey, Reston, Virginia: 2015
}

For more information on the USGS - the Federal source for science about the Earth, its natural and living resources, natural hazards, and the environment—visit http://www.usgs.gov or call 1-888-ASK-USGS.

For an overview of USGS information products, including maps, imagery, and publications, visit http://www.usgs.gov/pubprod/.

Any use of trade, firm, or product names is for descriptive purposes only and does not imply endorsement by the U.S. Government.

Although this information product, for the most part, is in the public domain, it also may contain copyrighted materials as noted in the text. Permission to reproduce copyrighted items must be secured from the copyright owner.

Suggested citation:

Whisnant, J.A., Hansen, C.V., and Eslick, P.J., 2015, Groundwater-level and storage-volume changes in the Equus Beds Aquifer near Wichita, Kansas, predevelopment through January 2015: U.S. Geological Survey Scientific Investigations Report 2015-5121, 27 p., http://dx.doi.org/10.3133/sir20155121.

ISSN 2328-0328 (online) 


\section{Acknowledgments}

The authors acknowledge the assistance of Michael Jacobs, Deb Ary, Scott Macey, Tim Boese, staff of the city of Wichita, and the Equus Beds Groundwater Management District Number 2 for providing potentiometric head data and for their technical reviews, which contributed to improved technical and editorial clarity of the report.

Technical reviews by U.S. Geological Survey employees Brian Kelly and Brian Klager also contributed to improved technical and editorial clarity of the report. 


\section{Contents}

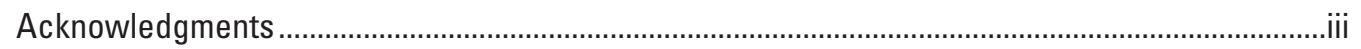

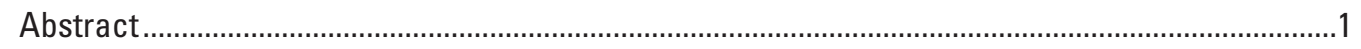

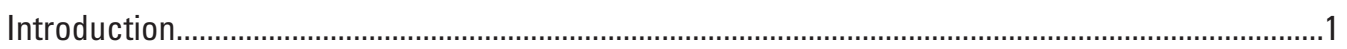

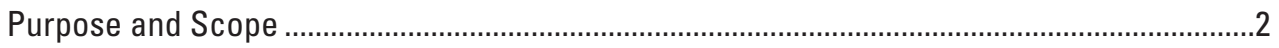

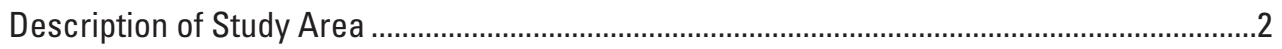

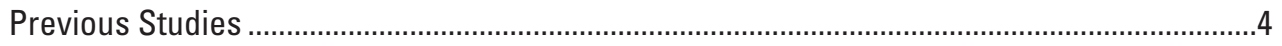

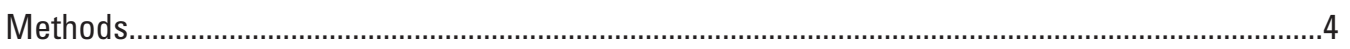

Shallow and Deep Parts of the Equus Beds Aquifer .............................................................

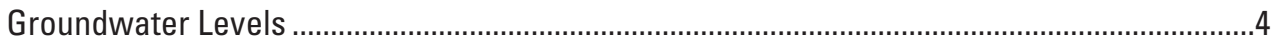

Groundwater-Level Measurements...........................................................................

Data Quality and Limitations ........................................................................................

Water-Level Altitudes.........................................................................................................

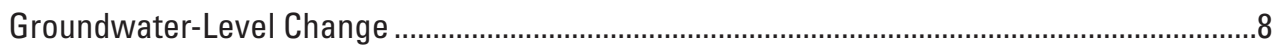

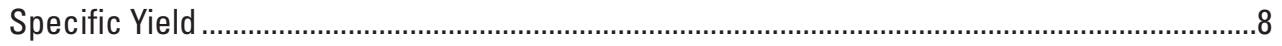

Total Aquifer Storage Volume ..........................................................................................

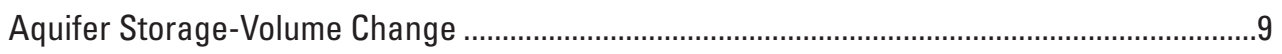

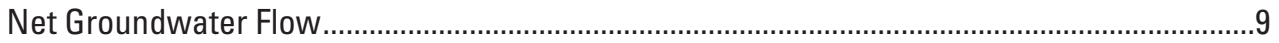

Potentiometric-Surface Maps, Predevelopment and January 2015...............................................9

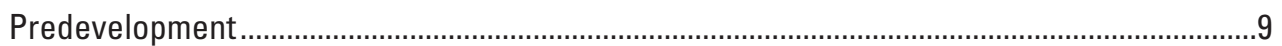

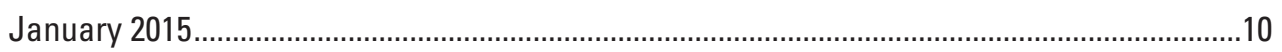

Groundwater-Level and Storage-Volume Changes in the Equus Beds Aquifer.............................10

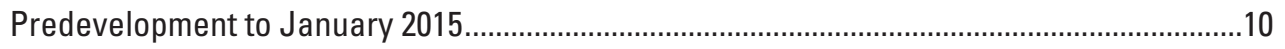

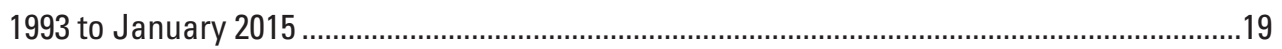

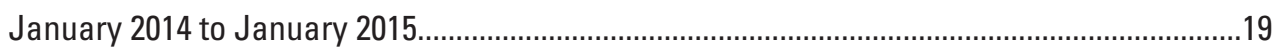

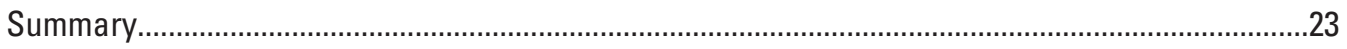

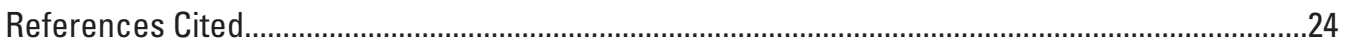

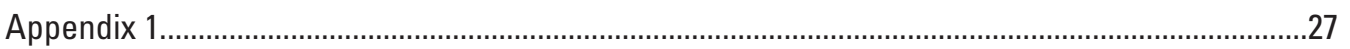




\section{Figures}

1. Map showing location of study area near Wichita, south-central Kansas ........................3

2. Graphs showing precipitation and water use, Kansas, 1938-2014 ..................................5

3. Graph showing annual groundwater use in the central part of the study area and in the rest of the study area, and average annual precipitation in the study area, 1988 through 2014

4. Map showing potentiometric surface of the shallow part of the Equus Beds aquifer, predevelopment

5. Map showing potentiometric surface of the shallow part of the Equus Beds aquifer, January 2015

6. Map showing depth to water in the shallow part of the Equus Beds aquifer, January 2015 ......

7. Map showing potentiometric surface of the deep part of the Equus Beds aquifer, January 2015

8. Graph showing storage-volume changes since predevelopment and since 1993 in the study area, the basin storage area, and the central part of the study area.

9. Map showing groundwater-level changes in the shallow part of the Equus Beds aquifer, predevelopment to January 2015

10. Map showing groundwater-level changes in the shallow part of the Equus Beds aquifer, 1993 to January 2015.

11. Map showing groundwater-level changes in the deep part of the Equus Beds aquifer, 1993 to January 2015 ...

12. Map showing groundwater-level changes in the shallow part of the Equus Beds aquifer, January 2014 to January 2015

\section{Tables}

1. Streamgages and low-head dams in and near the study area, south-central Kansas

2. Average groundwater-level changes, storage-volume changes, and total aquifer storage volume in the Equus Beds aquifer for various study areas near Wichita, south-central Kansas, predevelopment to January 2015

3. Volumetric water budget in the central part of the study area, 2013 to 2014 


\section{Conversion Factors}

Inch/Pound to International System of Units

\begin{tabular}{lcl}
\hline & Bultiply & \multicolumn{1}{c}{ To obtain } \\
\hline inch (in.) & Length & \\
inch (in.) & 2.54 & centimeter $(\mathrm{cm})$ \\
foot (ft) & 25.4 & millimeter $(\mathrm{mm})$ \\
mile (mi) & 0.3048 & meter $(\mathrm{m})$ \\
& 1.609 & kilometer $(\mathrm{km})$ \\
\hline acre & Area & \\
acre & 4,047 & square meter $\left(\mathrm{m}^{2}\right)$ \\
acre & 0.4047 & hectare $(\mathrm{ha})$ \\
square mile (mi $\left.{ }^{2}\right)$ & 0.004047 & square kilometer $\left(\mathrm{km}^{2}\right)$ \\
square mile (mi $\left.{ }^{2}\right)$ & 259.0 & hectare $(\mathrm{ha})$ \\
\hline & 2.590 & square kilometer $\left(\mathrm{km}^{2}\right)$ \\
\hline acre-foot (acre-ft) & Volume & \\
acre-foot (acre-ft) & 1,233 & cubic meter $\left(\mathrm{m}^{3}\right)$ \\
\hline & 0.325851 & million gallons $\left(\mathrm{Mgal}^{2}\right)$ \\
\hline acre-foot per year (acre-ft/yr) & Flow rate & \\
million gallons per day (Mgal/d) & 1,233 & cubic meter per year $\left(\mathrm{m}^{3} / \mathrm{yr}\right)$ \\
inch per year (in/yr) & 0.04381 & cubic meter per second $\left(\mathrm{m}^{3} / \mathrm{s}\right)$ \\
\hline
\end{tabular}

Temperature in degrees Celsius $\left({ }^{\circ} \mathrm{C}\right)$ may be converted to degrees Fahrenheit $\left({ }^{\circ} \mathrm{F}\right)$ as ${ }^{\circ} \mathrm{F}=\left(1.8 \times{ }^{\circ} \mathrm{C}\right)+32$

Temperature in degrees Fahrenheit $\left({ }^{\circ} \mathrm{F}\right)$ may be converted to degrees Celsius $\left({ }^{\circ} \mathrm{C}\right)$ as ${ }^{\circ} \mathrm{C}=\left({ }^{\circ} \mathrm{F}-32\right) / 1.8$

\section{Datums}

Vertical coordinate information is referenced to the North American Vertical Datum of 1988 (NAVD 88).

Horizontal coordinate information is referenced to the North American Datum of 1983 (NAD 83). Altitude, as used in this report, refers to distance above the vertical datum. 


\title{
Groundwater-Level and Storage-Volume Changes in the Equus Beds Aquifer near Wichita, Kansas, Predevelopment through January 2015
}

\author{
By Joshua A. Whisnant, Cristi V. Hansen, and Patrick J. Eslick
}

\section{Abstract}

Development of the Wichita well field began in the 1940s in the Equus Beds aquifer to provide the city of Wichita, Kansas, a new water-supply source. After development of the Wichita well field began, groundwater levels began to decline. Extensive development of irrigation wells that began in the 1970s also contributed to substantial groundwater-level declines. Groundwater-level declines likely enhance movement of brine from past oil and gas production near Burrton, Kansas, and natural saline water from the Arkansas River into the Wichita well field. Groundwater levels reached a historical minimum in 1993 because of drought conditions, irrigation, and the city of Wichita's withdrawals from the aquifer. In 1993, the city of Wichita adopted the Integrated Local Water Supply Program to ensure that Wichita's water needs would be met through the year 2050 and beyond as part of its efforts to manage the part of the Equus Beds aquifer Wichita uses. A key component of the Integrated Local Water Supply Program was the Equus Beds Aquifer Storage and Recovery project. The Aquifer Storage and Recovery project's goal is to store and eventually recover groundwater and help protect the Equus Beds aquifer from oil-field brine water near Burrton, Kansas, and saline water from the Arkansas River. Since 1940, the U.S. Geological Survey has monitored groundwater levels and storage-volume changes in the Equus Beds aquifer to provide data to the city of Wichita in order to better manage its water supply.

Groundwater mostly flowed from west to east in the shallow and deep parts of the Equus Beds aquifer in January 2015. A large area of declines greater than 10 feet in the shallow part of the Equus Beds aquifer from predevelopment (before substantial pumpage began in the area in September 1940) to January 2015 covered most of the central part of the study area, where the city of Wichita well field is located, and extended beyond it. Groundwater-level rises of greater than 10 feet from 1993 (the historical minimum groundwater levels) to January 2015 covered most of the central part of the study area in the shallow and deep parts of the Equus Beds aquifer; rises of greater than 20 feet mostly were within the north-central part of the study area. The 1993 to January 2015 recovery of storage volume previously lost from predevelopment to 1993 was about 46 percent $(55,200$ acre-feet) for the central part of the study area and the percentage recovery was larger than the 31 percent $(59,800$ acre-feet) recovery for the entire study area. Groundwater-level rises and the larger percentage recovery of storage volume in the central part of the study area was most likely a result of the city of Wichita adopting the Integrated Local Water Supply Program strategy which reduced Wichita's pumpage from the Equus Beds aquifer in 2014 to the smallest amount since 1940. January 2015 storage volumes were about 96 percent $(3,057,000$ acre-feet $)$ and 94 percent (960,000 acre-feet) of total aquifer storage for the study area and the central part of the study area, respectively.

Groundwater levels from January 2014 to January 2015 in the central part of the study area rose about 3 feet in some places, probably because Wichita reduced its withdrawals from the aquifer in 2014 by more than 50 percent. Groundwater levels probably recovered less than anticipated because of decreased recharge and net groundwater flow and increased agricultural pumpage. A volumetric water budget for the central part of the study area between 2013 and 2014 showed that the substantial decrease in total pumping $(10,412$ acrefeet) did not result in an increase in storage volume because it was more than offset by decreased recharge (6,502 acre-feet; artificial and from precipitation) and an even greater decrease in net groundwater flow (11,710 acre-feet).

\section{Introduction}

Development of the Wichita well field began in the 1940s in the Equus Beds aquifer to provide Wichita, the largest city in the State of Kansas, a new water-supply source (fig. 1; Williams and Lohman, 1949; Gibson, 1998; U.S. Census Bureau, 2012). The Wichita well field is located in southwest Harvey County and northwest Sedgwick County, Kansas, in an agricultural area; as such, the other primary use of water from the Equus Beds aquifer is for crop irrigation (Kansas Geological Survey and Kansas Department of Agriculture, 2015). After the Wichita well field's development began, groundwater levels in the Equus Beds aquifer began to decline (Williams 
and Lohman, 1949). Extensive development of irrigation wells began in the 1970s (Kansas Geological Survey and Kansas Department of Agriculture, 2015). Groundwater levels substantially declined in the Equus Beds aquifer because of city and irrigation withdrawals. As groundwater levels in the Equus Beds aquifer declined, the volume of water stored in the aquifer decreased, which reduced the amount of water available to supply Wichita's future needs. Groundwater-level declines are likely to cause movement or increased movement of brine from past oil and gas production near Burrton, Kans., and natural saline water from the Arkansas River (fig. 1) into the Wichita well field by increasing the hydraulic gradient toward the well field as groundwater-levels decline within it. Further movement into the Wichita well field of oil-field brine from Burrton, Kans., and saline water from the Arkansas River may limit use or require treatment of water from the Equus Beds aquifer for public supply and irrigation uses (Ziegler and others, 2010). Since 1940, the U.S. Geological Survey (USGS), in cooperation with the city of Wichita, has monitored groundwater levels and resulting storage-volume changes in the Equus Beds aquifer to provide data to the city of Wichita to enable Wichita to more effectively manage its water supply.

Groundwater levels reached a historical minimum in 1993 because of drought conditions, irrigation, and Wichita's withdrawals from the aquifer. This prompted Wichita to adopt, in 1993, the Integrated Local Water Supply Program (ILWSP) to ensure that water needs would be met through 2050 and beyond (City of Wichita, 2008, 2013; Desilva and Ary, 2011; Warren and others, 1995). The ILWSP includes the following strategies to increase the long-term (more than 50 years) sustainability of the Equus Beds aquifer: reliance on water sources other than the Equus Beds aquifer (fig. 1; for example, Cheney Reservoir), conservation encouragement, and development of the Equus Beds Aquifer Storage and Recovery (ASR) project with a designed artificial-recharge capacity of as much as 100 million gallons per day (Mgal/d) (City of Wichita, 2008, 2013; Desilva and Ary, 2011). The Equus Beds ASR project's goal is to store and eventually recover groundwater and help protect the aquifer from oil-field brine contaminated waters near Burrton, Kans., and saline waters from the Arkansas River (fig. 1; Ziegler and others, 2010). The Equus Beds ASR project diverts water from the Little Arkansas River and recharges it into the Equus Beds aquifer (fig. 1; City of Wichita, 2013). The artificial-recharge water is pumped either from the Little Arkansas River directly or from wells along the riverbank that obtain their water from the river by induced infiltration (fig. 1; City of Wichita, 2013). Phase I, which began operation in 2007, treats water pumped directly from the Little Arkansas River to reduce sediment and remove atrazine before it is recharged to the Equus Beds aquifer through recharge basins. Water pumped from riverbank wells does not receive additional treatment before it is recharged (Debra Ary, city of Wichita, written commun., 2012). For Phase II, which began operation in 2013, water is pumped from the Little Arkansas River, treated using ultrafiltration membranes and advanced oxidation techniques, delivered to recharge basins or recharge wells located throughout the Wichita well field, and then stored in the Equus Beds aquifer for future use (Debra Ary, city of Wichita, written commun., 2012).

\section{Purpose and Scope}

The purpose of this report is to present the groundwater levels and storage volumes in the Equus Beds aquifer in and around the Wichita well field northwest of Wichita in January 2015. Measured and estimated groundwater levels, and aquifer storage volumes, are presented in tabular form. Potentiometric-surface maps illustrate the groundwater levels in the shallow and deep parts of the Equus Beds aquifer. Potentiometricsurface maps are used to determine the groundwater-level and storage-volume changes in the aquifer since predevelopment (before substantial pumpage began in the area in September 1940) and since 1993 (the historical minimum groundwater levels). Historical precipitation and water-use information are presented. Information in this report can be used to document effects and improve understanding of water-resource management practices on the water supply in the Equus Beds aquifer, which is an important source of water for the city of Wichita.

\section{Description of Study Area}

The study area is located in the Equus Beds aquifer northwest of Wichita in Harvey and Sedgwick Counties, Kans., and between the Arkansas and Little Arkansas Rivers (fig. 1). The Equus Beds aquifer is the easternmost extent of the High Plains aquifer in Kansas (fig. 1; Stullken and others, 1985; Hansen and Aucott, 2001) and consists of sand and gravel interbedded with clay or silt (Lane and Miller, 1965; Myers and others, 1996). An area of sand dunes is located north of U.S. Highway 50 and south of the Little Arkansas River in the study area (fig. 1). The thick clay units that lie beneath the sand dunes restrict water movement and create confined (or semiconfined) conditions in the deep part of the Equus Beds aquifer (Kelly and others, 2013). The semiconfined conditions have resulted in groundwater-level and water-quality differences between the shallow and deep parts of the Equus Beds aquifer in this area (Stramel, 1956; Whittemore, 2007, 2012; Ziegler and others, 2010). Hansen and others (2014) provide a detailed description of the study area hydrogeology.

South-central Kansas, which includes the study area, is located in the eighth climate division of Kansas and characterized as a continental climate (National Oceanic and Atmospheric Administration, 2015). The study area is known for large variations in seasonal temperatures, precipitation, wind speed, and wind direction. The long-term average temperature based on the normal climate (1981 through 2010) ranged from 32.2 degrees Fahrenheit $\left({ }^{\circ} \mathrm{F}\right)$ in January to $81.1^{\circ} \mathrm{F}$ in July (National Oceanic and Atmospheric Administration, 2015). The long-term (1940 through 2014) annual average precipitation at weather stations in or near the study area (at or near 


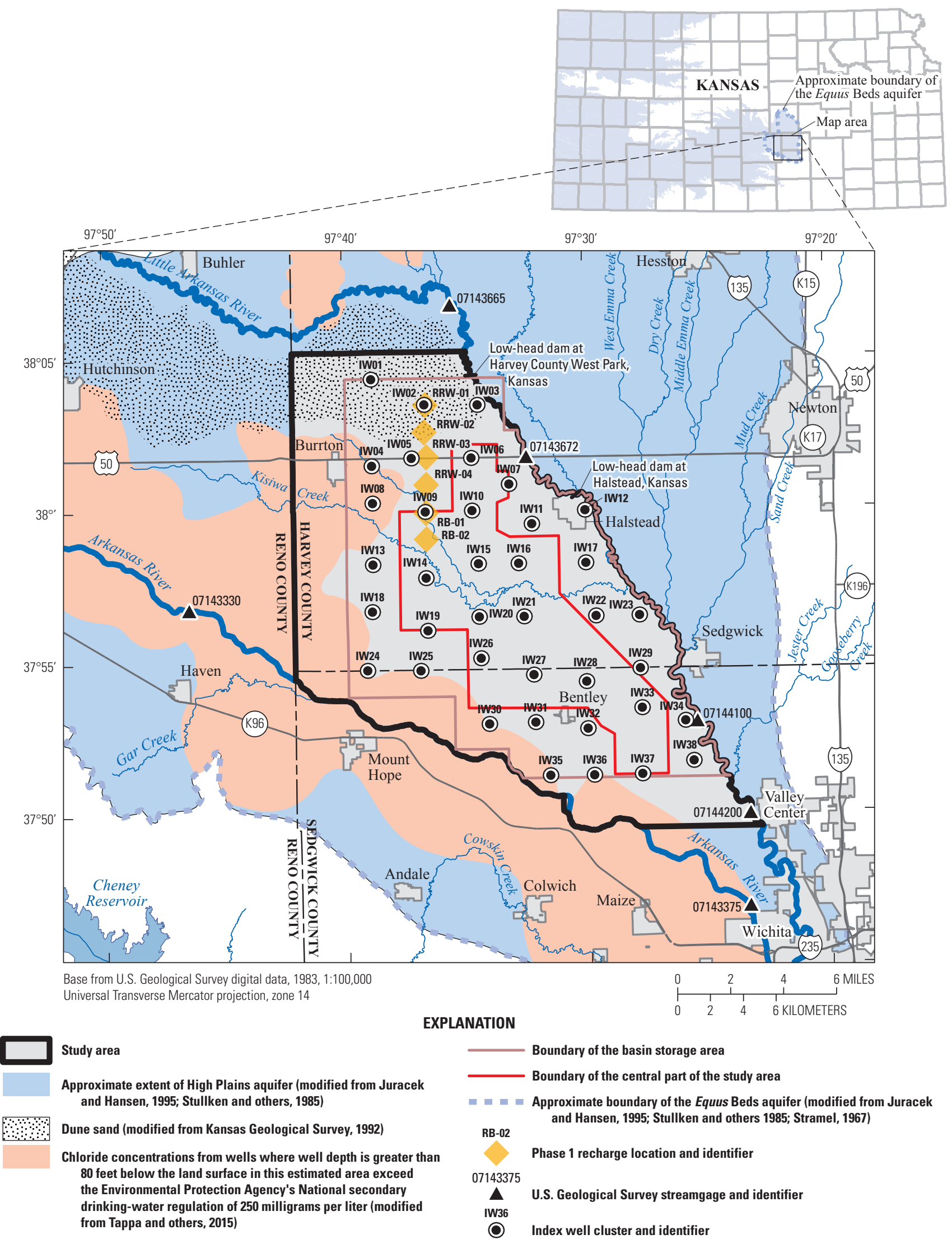

Figure 1. Location of study area near Wichita, south-central Kansas (modified from Hansen and others, 2014; and Tappa and others, 2015). 
Groundwater-Level and Storage-Volume Changes, Equus Beds Aquifer, Kansas, Predevelopment through January 2015

Bentley, Halstead, Hutchinson, Mount Hope, Newton, Sedgwick, and Wichita, Kans.) is 31.3 inches (in.; National Oceanic and Atmospheric Administration, 2015; fig. 2A).

The study area is 189 square miles $\left(\mathrm{mi}^{2}\right)$. The basin storage area is about $141 \mathrm{mi}^{2}$ and defined as the recharge credit accounting area by the Equus Beds ASR permit (fig. 1; Kansas Department of Agriculture, 2005). The basin storage area is used by the city of Wichita; the Equus Beds Groundwater Management District Number 2 (GMD2); and the Kansas Department of Agriculture, Division of Water Resources primarily for the purpose of determining where and how much artificial recharge can be pumped from the Equus Beds aquifer (Kansas Department of Agriculture, 2005). The central part of the study area (fig. 1) covers $55 \mathrm{mi}^{2}$ or about one-third of the study area.

Pumpage from the study area in 2014 was about 28,500 acre-feet (acre-ft) for irrigation use and about 9,700 acre-ft for the city of Wichita (fig. 2B; Jim Bagley, Kansas Department of Agriculture, written commun., 2015). Pumpage for the central part of the study area in 2014 was about 7,600 acre-ft for irrigation use and about 9,400 acre-ft for the city of Wichita (Jim Bagley, Kansas Department of Agriculture, written commun., 2015). The city of Wichita's pumpage for 2014 was less than any year since 1940 (fig. $2 B$ and 3). Hansen and others (2014) provide a detailed description of the study area, basin storage area, and central part of the study area.

\section{Previous Studies}

The Equus Beds aquifer (fig. 1) has been extensively studied because it is a water source for the city of Wichita, agriculture, and local industries. The USGS has provided the city of Wichita with status of groundwater levels and storage updates since the late 1940s (Williams and Lohman, 1949; Stramel, 1956; Stramel, 1967; Aucott and others, 1998). Kelly and others (2013) developed a model to simulate groundwater flow in the Equus Beds aquifer, Klager and others (2014) simulated chloride transport in the aquifer, Hansen and others (2014) described recent (2012 to 2014) groundwater-level and storage-volume changes in the aquifer, and Tappa and others (2015) described baseline water quality and the effects of artificial recharge on aquifer water quality. These reports include more exhaustive lists of previous studies.

\section{Methods}

This section describes methods used to determine the shallow and deep parts of the Equus Beds aquifer. Sources for measured groundwater, surface-water levels, precipitation, water-use data, and estimates of specific yield are discussed or displayed. Procedures to compute and estimate changes in groundwater levels and storage volumes are described. Data quality and limitations are also discussed. Parts of this section are taken verbatim from Hansen and others (2014).

\section{Shallow and Deep Parts of the Equus Beds Aquifer}

According to Hansen and others (2014, p. 7), "wells completed and screened in the Equus Beds aquifer were assigned to either the shallow or deep parts of the aquifer based on the depth of the bottom of the well casing or screened intervals to describe differences between the water levels of the different parts of the Equus Beds aquifer." Assignments were based on the Equus Beds Groundwater Management District Number 2 (GMD2) aquifer zone designations, and on well-completion and screen depths. The GMD2 has determined as many as four aquifer zones (designated AA, A, B, and C in order of increasing aquifer depth). These zones have clay layers in between that separate the zones (Tim Boese, Equus Beds Groundwater Management District Number 2, written commun., 2009). Zones A, B, and C are similar to upper, middle, and lower aquifer layers determined by Myers and others (1996). For the purpose of this report, wells designated by the GMD2 as completed in zones $\mathrm{A}$ and $\mathrm{C}$ were assigned to the shallow and deep parts of the Equus Beds aquifer, respectively. Hansen and others (2014, p. 7) stated, "a few wells designated by GMD2 as being in zone B that were deemed to be in the same zone as nearby basin storage area deep index wells were used to supplement interpretation of the deep water-level altitude maps."

Most monitoring wells of the city of Wichita have not been assigned to GMD2 zones, and some of these monitoring wells are located in clusters. Hansen and others (2014, p. 7) also stated, "the shallower of the wells in each city well cluster was assumed to be in and assigned to the shallow part of the Equus Beds aquifer; the deeper of the wells in each city well cluster was assumed to be in and assigned to the deep part of the Equus Beds aquifer." Ziegler and others (2010) used a depth of 80 feet ( $\mathrm{ft}$ ) as the dividing point between the shallow and deep parts of the Equus Beds aquifer. Hansen (2011) determined this to be a good threshold for separating the shallow and deep parts of the Equus Beds aquifer for wells that were not in clusters. Hansen and others (2014) provide a more detailed description on the division of aquifer parts.

\section{Groundwater Levels}

Annually, in the month of January, a groundwater-levelmeasurement effort is completed by the city of Wichita, GMD2, and USGS throughout the study area to best represent static conditions of the Equus Beds aquifer. Because January groundwater levels are expected to be as close to static conditions as possible, groundwater levels measured in January were given preference for this report (Hansen and others, 2014). All basin storage area index well (IW) (fig. 1) measurements were included in this report. Groundwater levels in the Equus Beds aquifer have been monitored by the city of 


\section{A. Precipitation}

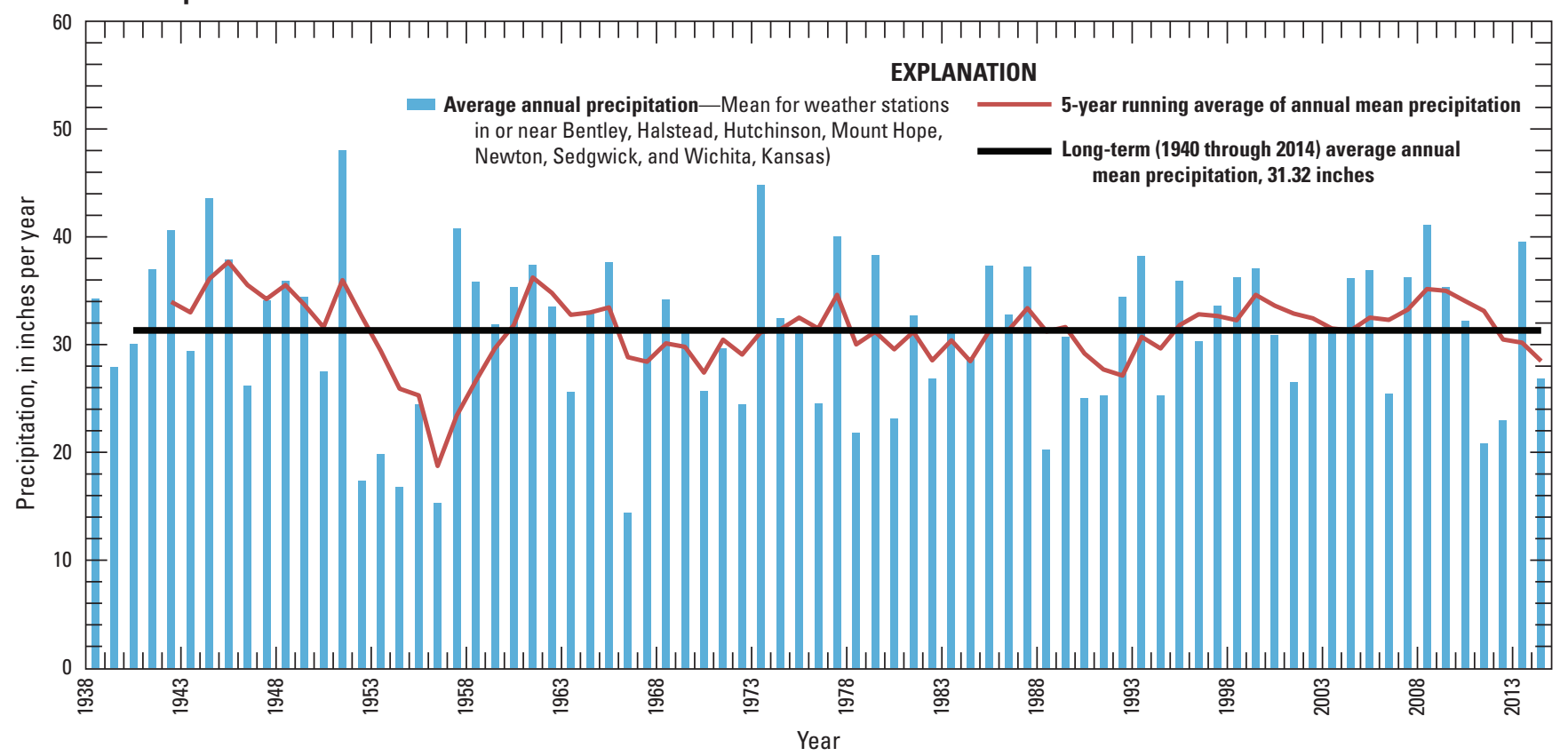

B. Water use for city of Wichita public supply and for agricultural irrigation

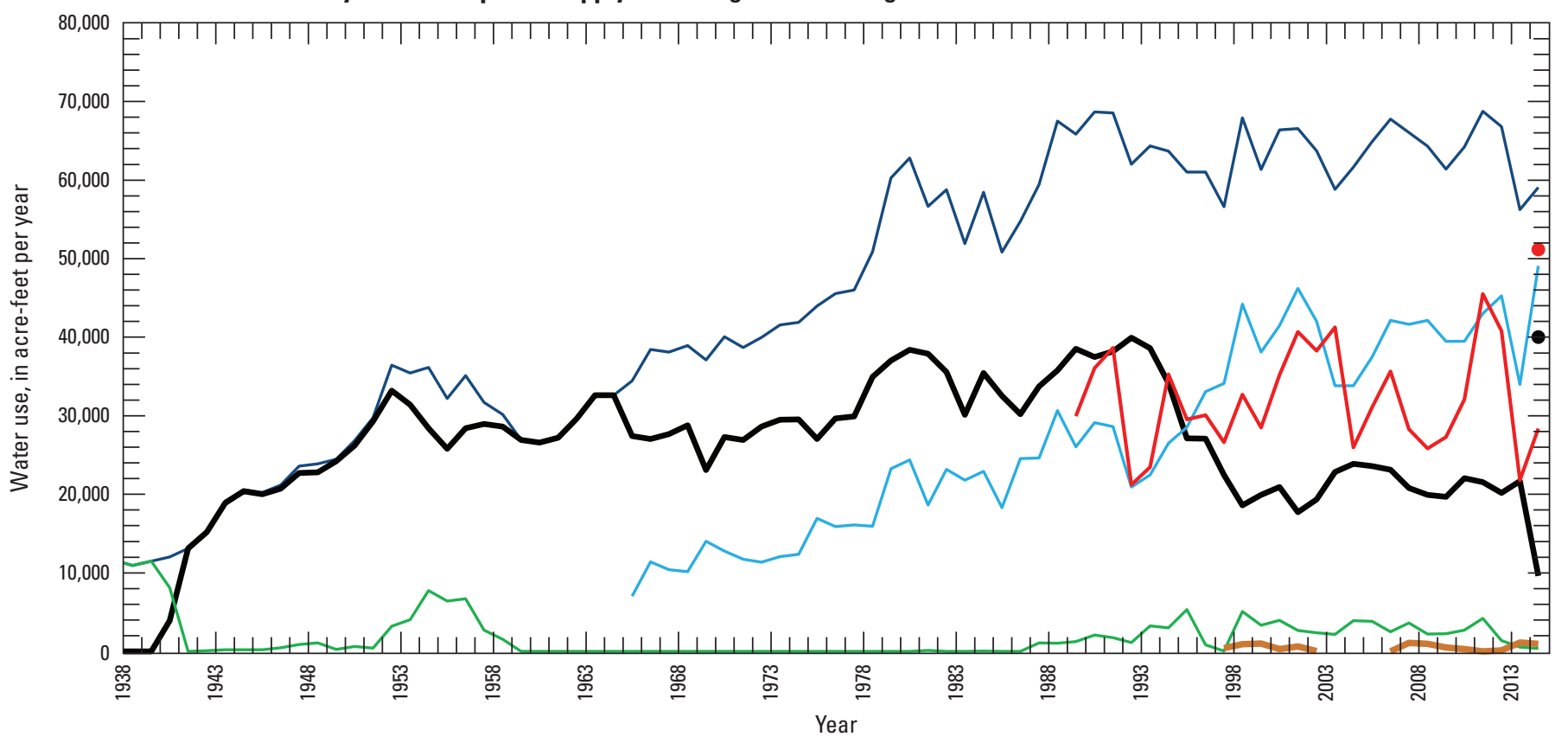

EXPLANATION

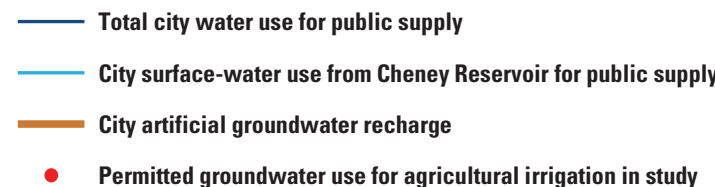

- Permitted groundwater use for agricultural irrigation in study area in 2014

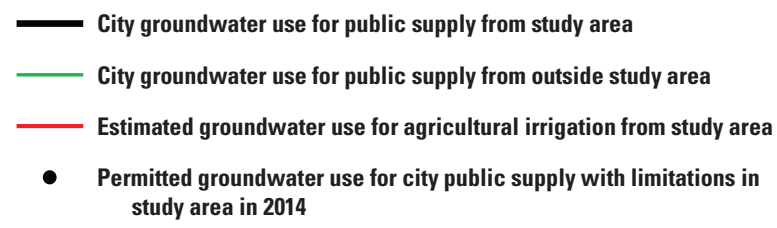
study area in 2014

Figure 2. Precipitation and water use, Kansas, 1938-2014. A, average annual precipitation for weather stations in or near Bentley, Halstead, Hutchinson, Mount Hope, Newton, Sedgewick, and Wichita, Kansas; 5-year running average of annual mean precipitation; and long-term average annual precipitation (National Oceanic Atmospheric Administration, 2015). $B$, water use for the city of Wichita public supply and agricultural irrigation (Wichita Water Department, [1959?]; Stramel, 1956, 1967; Kansas Geological Survey and Kansas Department of Agriculture, 2015; U.S. Geological Survey, 2015a; G.T. Blain, city of Wichita, written commun., 1997; Megan Schmeltz, city of Wichita, written commun., 2009; and Jim Bagley, Kansas Department of Agriculture, written commun., 2015). 
Wichita for decades using historic wells and other monitoring wells. Some historic production and monitoring wells in the central part of the study area were replaced as part of Phase II of the ASR project between 2009 and 2010 (Hansen and others, 2014). Historic wells were not used in this report when a new replacement well was located nearby. Between 2001 and 2002, IWs (fig. 1) were constructed to monitor artificial recharge effects on aquifer groundwater levels and water quality (Andrew Ziegler, U.S. Geological Survey, oral commun., 2003). Phase I of the ASR project constructed monitoring wells near the six ASR Phase I artificial recharge sites (fig. 1). Phase II of the ASR project installed new wells in 2009 and 2010 to monitor Phase II artificial recharge effects on aquifer water quality (Hansen and others, 2014; Andrew Ziegler, U.S. Geological Survey, written commun., 2014). Hansen and others (2014, p. 7) stated, "the GMD2 monitoring wells were installed for GMD2 beginning in 1978 or are existing wells used by GMD2 to monitor the Equus Beds aquifer."

\section{Groundwater-Level Measurements}

Groundwater levels were measured January 5-30, 2015. A total of 360 wells were measured and include 191 historic city of Wichita monitoring or production wells (or their replacements), 76 IWs, 39 Phase I and II monitoring wells, and 54 wells monitored by GMD2. These data were used to represent static groundwater-level conditions for January 2015 in the shallow and deep parts of the Equus Beds aquifer in the study area. Additional groundwater levels from historic city of Wichita monitoring wells and GMD2 monitoring wells in the shallow and deep parts of the Equus Beds aquifer outside of the study area were used to improve analyses near the boundaries of the study area (Hansen and others, 2014).

These wells outside of the study area are not presented in this report. Groundwater levels were measured by personnel from the USGS, GMD2, and city of Wichita. According to Hansen and others (2014, p. 8), "all agencies used standard water-level

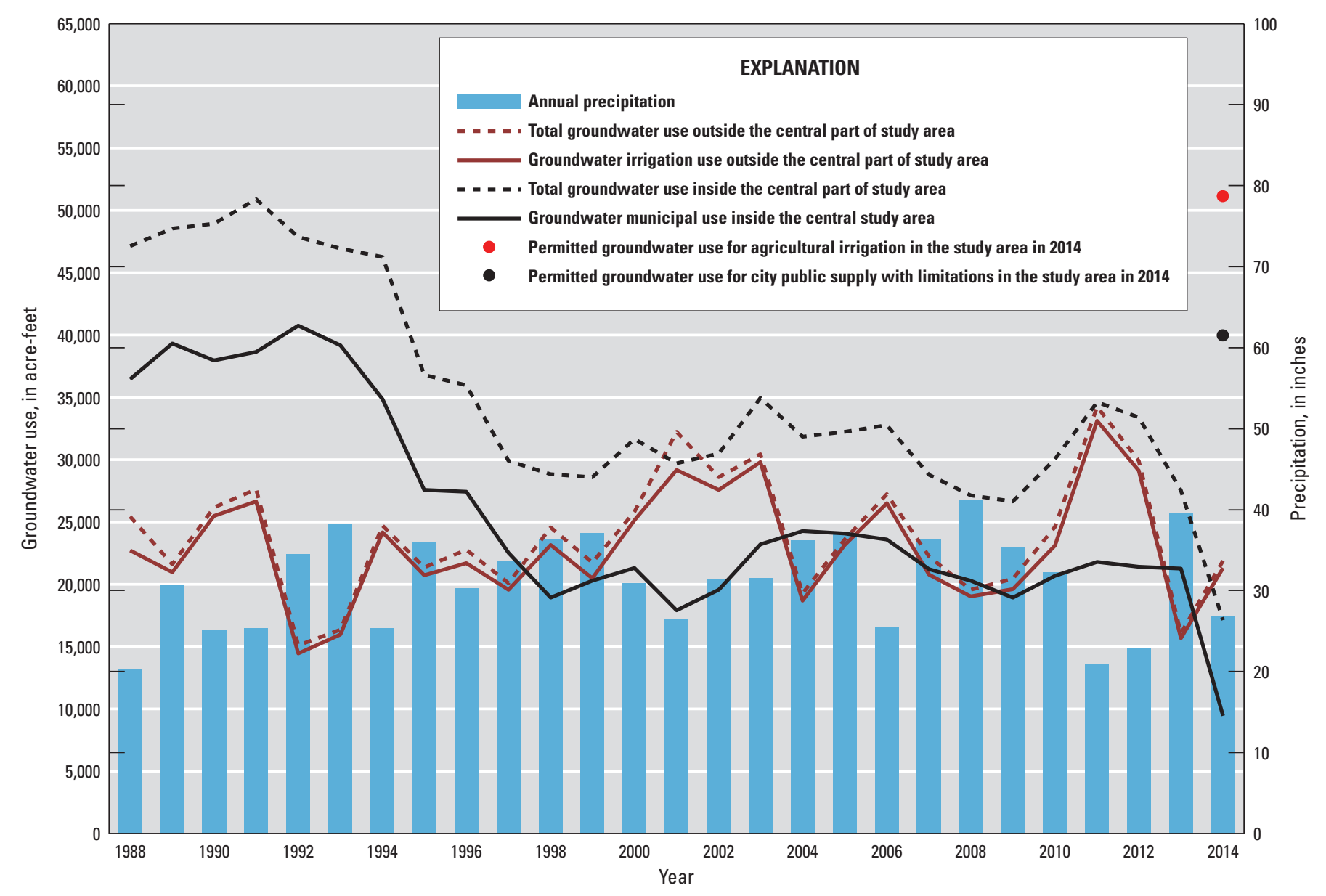

Figure 3. Annual groundwater use in the central part of the study area and in the rest of the study area, and average annual precipitation in the study area, 1988 through 2014. Water-use data are from Kansas Geological Survey and Kansas Department of Agriculture (2015) and Jim Bagley, Kansas Department of Agriculture (written commun., 2015); precipitation data are from National Oceanic and Atmospheric Administration (2015). 
measurement techniques that are similar to USGS methods described in Cunningham and Schalk (2011)". Data collected by GMD2 are stored in the Kansas Geological Survey Water Information Storage and Retrieval Database (WIZARD; Kansas Geological Survey, 2015). Data collected by the USGS are stored in the USGS National Water Information System (NWIS) database (U.S. Geological Survey, 2015b). Data collected by the city of Wichita are stored on file with the Public Works and Utilities Department in Wichita. The measured groundwater levels used for this report are stored in NWIS.

\section{Data Quality and Limitations}

Hansen and others (2014, p. 8) stated, "most of the water-level data used in this report were collected for other purposes by the city of Wichita and GMD2. The quality of the water-level data for each well was evaluated by examining hydrographs summarizing all water-level data for each well." Measurements were rounded to the nearest hundredth of a foot for this report. January 2015 potentiometric-surface maps represent as close to static conditions as possible. Groundwaterlevel measurements that depicted conditions other than static were not used in this report. Groundwater levels that were noted as being from recent (within the previous week) pumping wells or near recent pumping wells were not used (Hansen and others, 2014). Groundwater levels may have changed since groundwater levels were measured for this report.

Rasters, which are areal grids with a value assigned to all individual cells, were interpolated from point data derived from measured groundwater levels. Point data are interpolated by algorithms used by a geographic information system (GIS) to make the rasters (Esri, 2014b). A raster cell size of 10 meters $(\mathrm{m})$ by $10 \mathrm{~m}$ was used to reduce error potential. Contours generated from rasters required slight manual modification to better represent measured point data. Hansen and others $(2014$, p. 8) stated, "as a result, the value of the raster may not exactly match a measured value at the same location."

\section{Water-Level Altitudes}

Potentiometric surface is defined by Lohman (1972, p. 8) in relation to an aquifer as, "the levels to which water will rise in tightly cased wells." Water-level altitudes used in this report are either stored in NWIS or computed by subtracting the depth to water below the land surface from the land-surface altitude. Land-surface altitudes at wells are those stored in NWIS or WIZARD (Hansen and others, 2014). Land-surface altitudes referenced to the National Geodetic Vertical Datum of 1929 (NGVD 29) previously were converted to North American Vertical Datum 88 (NAVD 88) by Hansen and others $(2013,2014)$; all water-level altitudes are referenced to the NAVD 88. Predevelopment (generally before 1940 when substantial pumpage began in the study area) and 1993 (the historical minimum groundwater levels) water-level altitudes used in this report were measured or interpolated by Hansen and others (2013), or were determined from the rasters used by Hansen and others (2013). The interpolated water-level altitude was determined by intersecting the well's location with the appropriate raster (predevelopment, 1993, or January 2014) of the potentiometric surface of the appropriate part of the Equus Beds aquifer constructed by Hansen and others (2013) or made for this report and applying the water-level altitude of the raster at that location to the well (Hansen and others, 2014). Measured and interpolated water-level altitudes used for this report are included in table 1-1 in the appendix.

"Surface-water altitudes from six streamgages and two low-head dams were used as additional data points to adjust contours of the shallow part of the Equus Beds aquifer" according to Hansen and others $(2014$, p. 9) (fig. 1; table 1). Average daily surface-water altitudes for mid-January were used as additional data points. These values were obtained from NWIS for the streamgages (U.S. Geological Survey, $2015 b)$. The altitudes of the tops of the two low-head dams were used as the surface-water altitude at the dams (Trudy Bennett, U.S. Geological Survey, written commun., 2009).

Table 1. Streamgages and low-head dams in and near the study area, south-central Kansas.

[USGS, U.S. Geological Survey; NAVD 88, North American Vertical Datum of 1988; --, not applicable]

\begin{tabular}{|c|c|c|}
\hline $\begin{array}{c}\text { USGS site } \\
\text { identification number } \\
\text { (fig. 1) }\end{array}$ & Site name & $\begin{array}{c}\text { Altitude of surface-water } \\
\text { level January } 2015 \\
\text { (feet above NAVD 88) }\end{array}$ \\
\hline 07143330 & Arkansas River near Hutchinson, Kansas & $1,456.51$ \\
\hline 07143375 & Arkansas River near Maize, Kansas & $1,322.93$ \\
\hline 07143665 & Little Arkansas River at Alta Mills, Kansas & $1,391.94$ \\
\hline 07143672 & Little Arkansas River at Highway 50 near Halstead, Kansas & $1,376.91$ \\
\hline 07144200 & Little Arkansas River at Valley Center, Kansas & $1,326.98$ \\
\hline-- & Low-head dam on the Little Arkansas River at Harvey County West Park, Kansas & $1,390.38$ \\
\hline-- & Low-head dam on the Little Arkansas River at Halstead, Kansas & $1,375.78$ \\
\hline
\end{tabular}


Water-level altitudes were entered into ArcGIS, and rasters were created using the "Topo to Raster" tool in ArcGIS (Esri, 2014b). Separate rasters were created for the shallow and deep parts of the Equus Beds aquifer. Contours, with a 5 - $\mathrm{ft}$ interval, were created from the rasters using the "Contour" tool in ArcGIS (Esri, 2014a). Contours were manually modified as needed to better match the measured water-level altitudes. Water-level altitude contour constraints used in this report are similar to those used by Hansen and others (2014) and included the following: all contours remained below the land surface with exceptions at known surface-water locations, contours for the deep part of the Equus Beds aquifer would remain below those for the shallow part except where measurements from clustered wells indicated otherwise or streams were gaining, and 1993 contours for the shallow and deep parts were used as guides to help place 2015 contours (Hansen and others, 2013). New rasters were created using measured values and revised contours; these rasters were used to estimate groundwater-level and storage-volume changes in the study area.

\section{Groundwater-Level Change}

Groundwater-level change maps used in this report were developed using methods described in detail in Hansen and others (2013). Existing potentiometric surfaces (1993 and January 2014) and a newly created predevelopment surface for the shallow part of the Equus Beds aquifer were subtracted from newly created potentiometric surfaces for January 2015 for the shallow part of the Equus Beds aquifer. An existing potentiometric surface for 1993 in the deep part of the Equus Beds aquifer was subtracted from a newly created potentiometric surface for January 2015 for the deep part of the Equus Beds aquifer. Differences in water-level-altitude measurements between each period were computed and displayed using rasters. Contours, with 5 -ft intervals, were created using the computed differences, and contour revisions were made manually to better match measured data. Average groundwater-level change was computed in three ways: at wells with measurements for the periods, at wells with measurements for the end period (January 2015) and interpolated groundwater levels for the beginning of the period (predevelopment, 1993, January 2014), and using the raster subtraction method.

\section{Specific Yield}

Specific yield is the ratio of the volume of water that the saturated rock or soil yields by gravity to the volume of rock or soil (Lohman, 1972). Previous studies, including Hansen and others $(2013,2014)$, used a specific yield value of 0.15 because the value was in the range of most estimates and matched the specific yield used by recent groundwater-flow and transport models of the Equus Beds aquifer (Kelly and others, 2013; Klager and others, 2014). Hansen and others (2014, p. 10) stated, "specific yield may be used with the volume of water-level change in the unconfined part of the aquifer to estimate increases or decreases in available water in storage in the Equus Beds aquifer."

The Equus Beds aquifer is unconfined; however, some areas show semiconfined conditions due to the presence of clay layers. (Spinazola and others, 1985; Stramel, 1967). If the shallow part of the Equus Beds aquifer is unconfined and the deep part is semiconfined to confined, the use of specific yield is only appropriate for the shallow part of the aquifer to estimate storage-volume change. A storage coefficient must be used to estimate the storage-volume change for the deep part of the aquifer where it is semiconfined or confined. Kelly and others (2013) used a specific yield of 0.15 where the Equus Bed aquifer was unconfined and a storage coefficient of 0.0005 where the Equus Beds aquifer was semiconfined to confined. According to Hansen and others (2014, p. 25), "use of specific yield and water-level changes in the deep part of the Equus Beds aquifer where it is semiconfined to confined will overestimate the amount of storage-volume change by a factor close to 300 . Therefore, although water-level changes in the deep part of the Equus Beds aquifer may be larger than those of the shallow part of the Equus Beds aquifer in semiconfined to confined areas, the contribution of the deep part to total storage-volume change will be small." Kelly and others (2013) state:
Use of groundwater-level changes that do not include storage changes that occur in confined or semi-confined parts of the aquifer will slightly underestimate storage changes; however, use of specific yield and groundwater-level changes to estimate storage change in confined or semi- confined parts of the aquifer will overestimate storage changes. Using only changes in shallow groundwater levels will provide more accurate stor- age changes for the measured groundwater-levels method.

This leads to groundwater-level changes in the shallow part of the Equus Beds aquifer being more appropriate in determining changes in storage volume. Hansen and others (2014) and Kelly and others (2013) provide a detailed description of specific yield in the Equus Beds aquifer.

\section{Total Aquifer Storage Volume}

Total storage volume of the aquifer was estimated using the groundwater-flow model developed by Kelly and others (2013). This model computed total storage volume by multiplying the predevelopment saturated thickness of the Equus Beds aquifer in each cell by the cell area, summing the volume of cells within a specified area, and then multiplying by a specific yield of 0.15 . Total aquifer storage volume during predevelopment for the study area, basin storage area, and central part of the study area based on model results were 3,192,000, 2,400,000, and 1,025,000 acre-ft, respectively (Hansen and others, 2013). 


\section{Aquifer Storage-Volume Change}

Aquifer storage-volume change is the change in aquifer saturated thickness multiplied by the area of the aquifer containing the change multiplied by specific yield. This was determined using the "Map Algebra" tool in ArcGIS (Esri, 2014c) to subtract aquifer storage-volume change for the period of interest, for example January 2015, from the predevelopment aquifer storage volume. As noted by Hansen and others (2014), the change in storage volume of the Equus Beds aquifer is estimated this way instead of by computing the difference between two total aquifer storage volumes because of the large uncertainty in the total aquifer storage volume, and the amount of storage-volume change to date (2015) is small compared to the total aquifer storage volume.

Storage-volume change was estimated for this report in two ways in order to check for accuracy of the estimations. One method for estimation subtracted the storage-volume change for the necessary time period's raster (January 2015 for example) from predevelopment or 1993 storage-volume change estimated by Hansen and others (2013). Groundwaterlevel-change rasters also were used to estimate storage-volume change. The groundwater-level-change rasters were converted to contours, plotted with measured groundwater-level changes at the wells, and the contours were modified to conform to the measured groundwater-level changes and make hydrologic sense. Using modified contours, a new groundwaterlevel-change raster was created. The area of each cell of the groundwater-level-change raster was multiplied by the groundwater-level change for that cell; the resulting value for each cell was multiplied by a specific yield of 0.15 to estimate the storage-volume change in each raster cell. Storage-volume changes were summed over a given area (study area, basin storage area, or central part of the study area) to determine storage-volume change for that area using the "Zonal Statistics" tool in ArcGIS (Esri, 2014d). Hansen and others (2014, p. 10) stated, "to avoid implying unsupported precision in the estimates of storage-volume change, the values were reported only to three significant figures."

\section{Net Groundwater Flow}

The net groundwater flow used in the volumetric water budget in this report was estimated by the following equation:

$$
Q_{G W}=\Delta_{S}+P_{G W}-R_{p}-R_{A}
$$

where

$$
\begin{gathered}
Q_{G W} \quad \begin{array}{l}
\text { is the net groundwater flow (inflow minus the } \\
\text { outflow) in the central part of the study } \\
\text { area; }
\end{array} \\
\Delta_{S} \quad \begin{array}{l}
\text { is the storage-volume change in the central } \\
\text { part of the study area; }
\end{array} \\
P_{G W} \quad \begin{array}{l}
\text { is the total groundwater pumping in the } \\
\text { central part of the study area; }
\end{array}
\end{gathered}
$$

$R_{p} \quad$ is the recharge from precipitation in the central part of the study area; and

$R_{A} \quad$ is the artificial recharge in the central part of the study area.

Storage-volume change was estimated from the water-level change map, total groundwater pumpage was calculated from the annual groundwater pumpage reported to the Kansas Department of Agriculture (Kansas Geological Survey and Kansas Department of Agriculture, 2015), recharge from precipitation was estimated as 17 percent of the actual annual precipitation (Kelly and others, 2013; National Oceanic and Atmospheric Administration, 2015), and artificial recharge was calculated from the artificial recharge reported by the city of Wichita (U.S. Geological Survey, 2015a).

\section{Potentiometric-Surface Maps, Predevelopment and January 2015}

A potentiometric-surface map indicates the height of the water surface above a datum and direction of flow. The potentiometric surface in an unconfined aquifer is the water table. Water within the aquifer moves from higher to lower waterlevel altitudes. Water moves orthogonally to the potentiometric contours in the horizontal assuming a homogeneous and isotropic aquifer. When the groundwater level is higher in the shallow than in the deep part of the aquifer, water moves in a downward direction. Groundwater levels may be substantially different in the deep part versus the shallow part of the aquifer in confined or semiconfined aquifers. Efforts were made to include only static groundwater levels and wells completed in single parts of the Equus Beds aquifer for each map in this report.

\section{Predevelopment}

The previously published predevelopment potentiometric surface of the shallow part of the Equus Beds aquifer (Hansen and others, 2013) was revised because the value used for the predevelopment groundwater level at well P34AA was changed from the 1939 measurement to the April 1940 measurement. Examination of the groundwater levels in well P34AA, which is along the northern boundary of the study area (fig. 4), shows these levels declined almost $30 \mathrm{ft}$ from the measurements in 1939 (used for the predevelopment groundwater level by Williams and Lohman, 1939; and Hansen and others, 2013) to April 1940 and have never been recorded as recovering closer than within $15 \mathrm{ft}$ of the 1939 level (U.S. Geological Survey, 2015b). This large decline over a short period with no supporting cause and lack of recovery to an equal level since then have led to doubt of the accuracy of the 1939 water level. For this reason, the April 1940 water level was used as the predevelopment (before substantial 
pumping began in the area) water level for well P34AA in this report and the predevelopment potentiometric-surface map was revised (fig. 4). The main difference between this revised predevelopment potentiometric surface map of the shallow part of the Equus Beds aquifer and that from Hansen and others (2013) was in the northwestern part of the study area where the contours between P34AA and P32AA were shifted southward, which decreased the size of the area of recharge and increased the hydraulic gradient toward P34AA.

\section{January 2015}

Potentiometric contours indicate that groundwater flow within the shallow part of the Equus Beds aquifer was mostly west to east in January 2015, which is common in the aquifer (fig. 5; Hansen and others, 2014). Groundwater levels in the shallow part of the aquifer ranged from about 1,470 $\mathrm{ft}$ in the northwest part of the study area to about $1,325 \mathrm{ft}$ in the southeast part of the study area (fig. 5). Most of the study area had a depth to water in the shallow part of the Equus Beds aquifer greater than $10 \mathrm{ft}$ (fig. 6). An area of recharge in the shallow part of the Equus Beds aquifer can be seen in the northwest part of the study area as evidenced by the closed 1,465 and 1,470 potentiometric contours (fig. 5). "The depth to water in the shallow part of the Equus Beds aquifer is greatest in the northwest part of the study area and the northern part of the central part of the study area (fig. 6). Potentiometric contours show that groundwater flow generally was from west to east within the deep part of the Equus Beds aquifer in January 2015 (fig. 7). Groundwater levels in the deep part of the Equus Beds aquifer ranged from more than 1,440 ft in the west part of the study area to $1,325 \mathrm{ft}$ in the southeast part of the study area (fig. 7).

\section{Groundwater-Level and Storage- Volume Changes in the Equus Beds Aquifer}

Comparing water-level altitudes between two time periods indicates the areal distribution and magnitude of groundwater-level rises and declines. The change in groundwater level multiplied by the specific yield estimates the areal distribution and magnitude of storage-volume changes in the Equus Beds aquifer. Average groundwater-level change for the study area, basin storage area, and central part of the study area from predevelopment (before substantial pumpage began in the area in September 1940) to January 2015 for the shallow part and from 1993 to January 2015 for the shallow and deep parts of the Equus Bed aquifer are provided in table 2. The low predevelopment data density did not allow computation of average groundwater-level change since predevelopment for the deep part of the Equus Beds aquifer (Hansen and others, 2013). Most of the water coming out of storage is from the unconfined (shallow) part of the aquifer. In aquifers that are semiconfined to confined, water coming out of storage is from expansion of water and aquifer compression rather than dewatering of the aquifer (Heath, 1983).

\section{Predevelopment to January 2015}

Groundwater levels mostly declined in the shallow part of the aquifer from predevelopment to January 2015 in the study area, basin storage area, and central part of the study area (figs. 8 and 9). Average groundwater-level declines from predevelopment to January 2015 in the shallow part of the aquifer were greater in the central part of the study area than in either the basin storage area or the entire study area (table 2). A large area of declines of greater than $10 \mathrm{ft}$ in the shallow part of the aquifer covered most of the central part of the study area, and extended beyond it to the north and west where there were declines greater than $20 \mathrm{ft}$. Another area of declines greater than $10 \mathrm{ft}$ from predevelopment to January $2015 \mathrm{in}$ the shallow part of the aquifer was in the extreme northwest corner of the study area (fig. 9). Because the area of decline greater than $20 \mathrm{ft}$ is outside the central part of the study area (where city of Wichita pumpage happens), it probably was not caused by city pumpage from the Equus Beds aquifer. An area of groundwater-level rise from predevelopment to January 2015 is in the northwest corner of the study area near IW01A (fig. 9). This area of groundwater-level rise may be partly an artifact of the predevelopment and January 2015 potentiometric-surface contours and rasters used to make the predevelopment to January 2015 water-level change map because the area contains few measured wells and none with predevelopment and January 2015 measured values.

Study-area storage volume from predevelopment to January 2015 decreased about 135,000 acre-ft (table 2). The study-area storage-volume decrease from predevelopment to January 2015 represents a 4 percent loss of total aquifer storage volume (table 2). The central part of the study area accounted for about 46 percent of the predevelopment to January 2015 storage-volume decrease in the study area (table 2). The current (2015) remaining storage volume of the Equus Beds aquifer in the central part of the study area was estimated to be about 960,000 acre- $\mathrm{ft}$, which was less than the previous year's estimation of about 962,000 acre-ft (Hansen and others, 2014). A more detailed numeric breakdown of the storage volume and differences is provided in table 2. Storage-volume changes since predevelopment in the shallow part of the Equus Beds aquifer in the study area and basin storage area have been recovering some of the storage volume that was lost in the past few years (figs. 8 and 9); though in the central part of the study area storage-volume changes have remained roughly consistent in the past few years (figs. 8 and 9). 


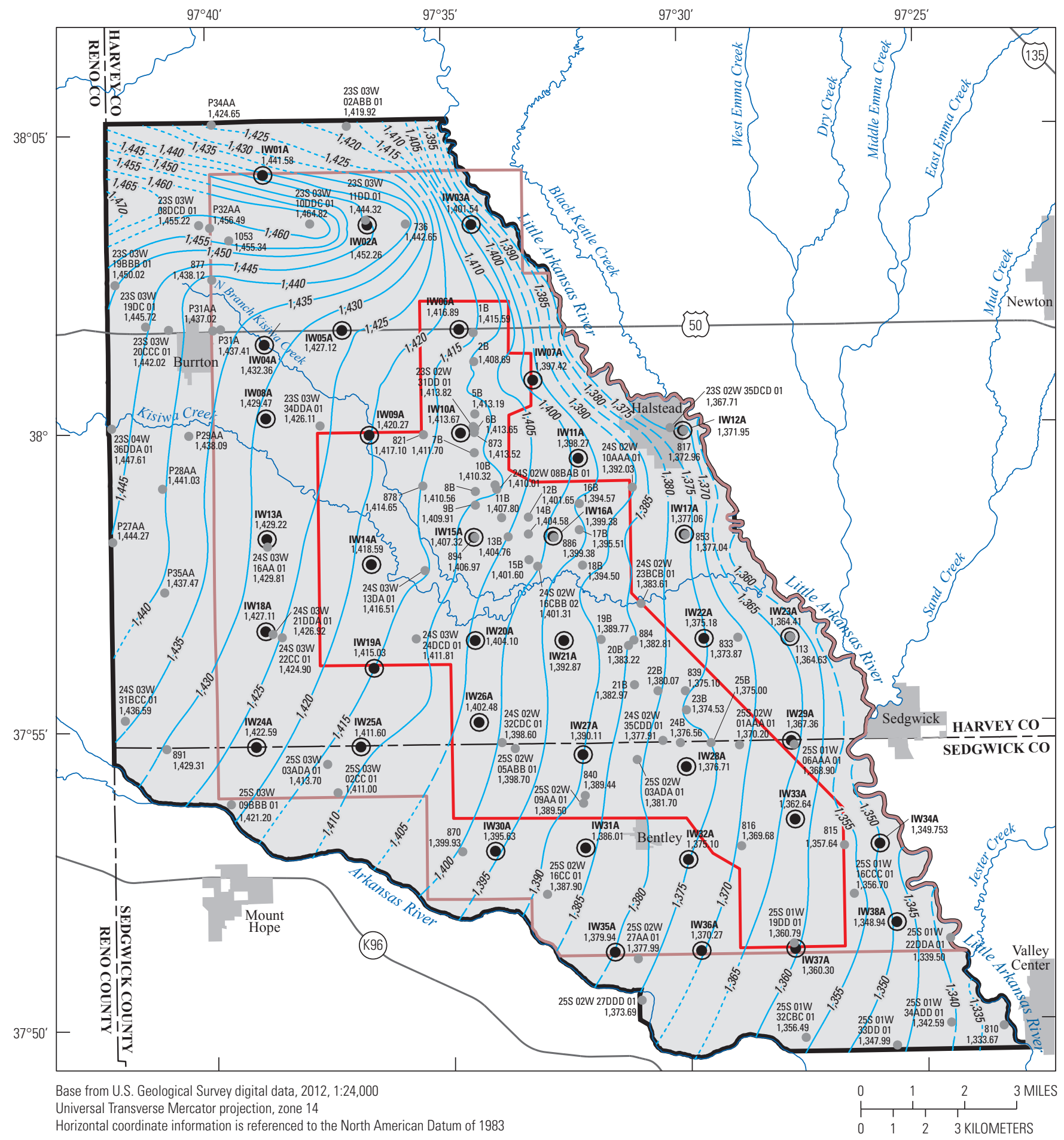

EXPLANATION

Study area

Boundary of basin storage area

Boundary of central part of the study area
-1,385 - Potentiometric contour-Shows altitude at which water level would have stood in tightly cased
wells in the shallow part of the Equus Beds aquifer, predevelopment. Dashed where
approximately located. Short dash where inferred. Contour interval 5 feet. Datum is North
American Vertical Datum of 1988
1,37359.936
Index monitoring well in the shallow part of the Equus beds aquifer-Well identifier shown above; interpolated predevelopment groundwater-level altitude, in feet, shown below

25S 02W 27DDD $01-$ Monitoring well in the shallow part of the Equus beds aquifer-Well identifier shown above; measured predevelopment groundwater-level altitude, in feet, shown below

Figure 4. Potentiometric surface of the shallow part of the Equus Beds aquifer, predevelopment. 


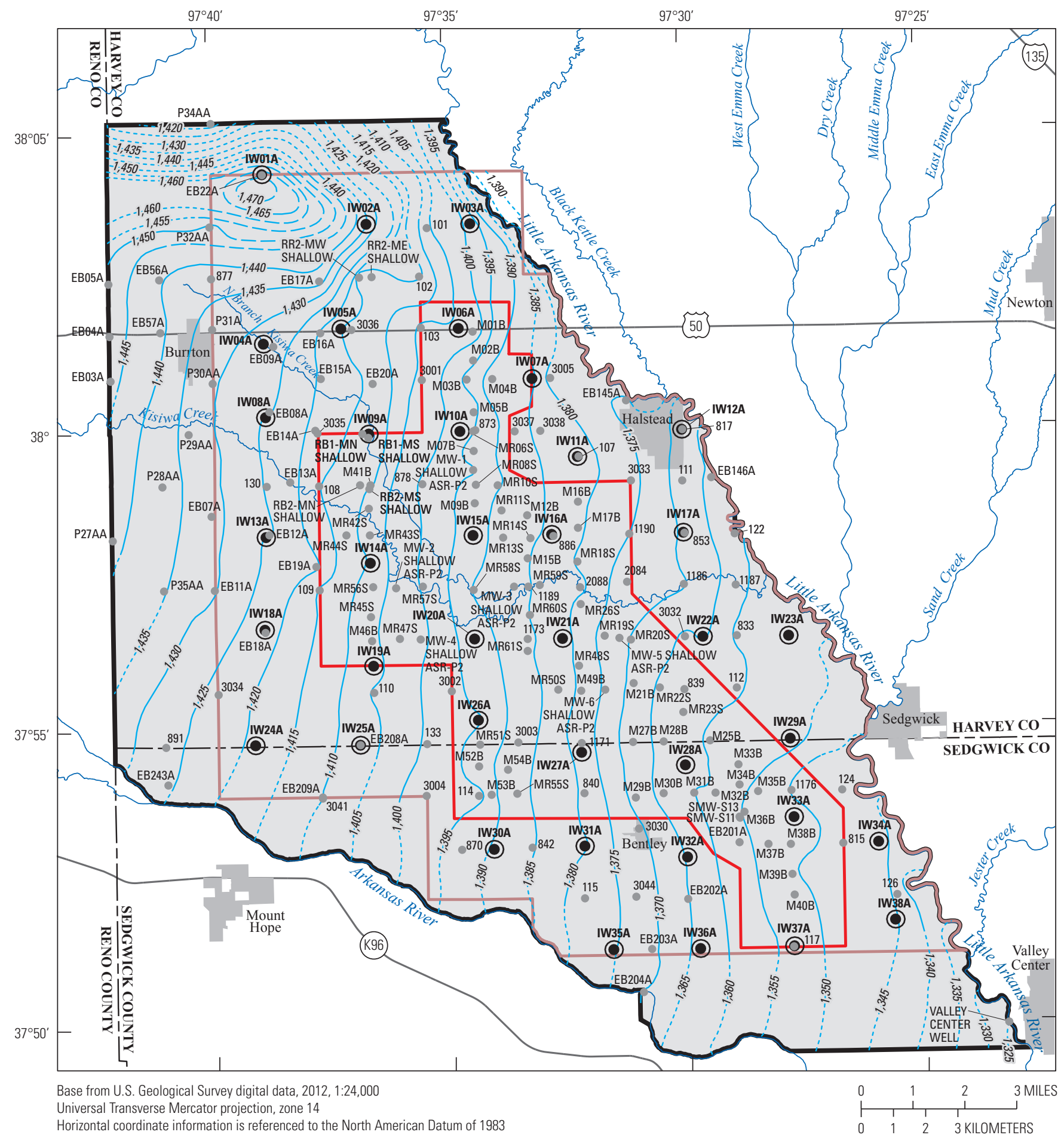

EXPLANATION
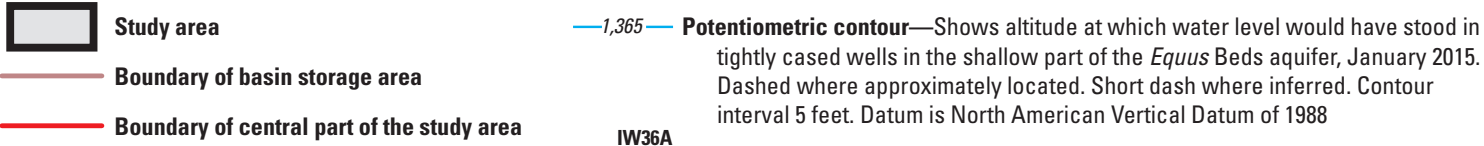

( Index monitoring well and identifier in the shallow part of the Equus beds aquifer

EB204A Monitoring well and identifier in the shallow part of the Equus beds aquifer

Figure 5. Potentiometric surface of the shallow part of the Equus Beds aquifer, January 2015. 


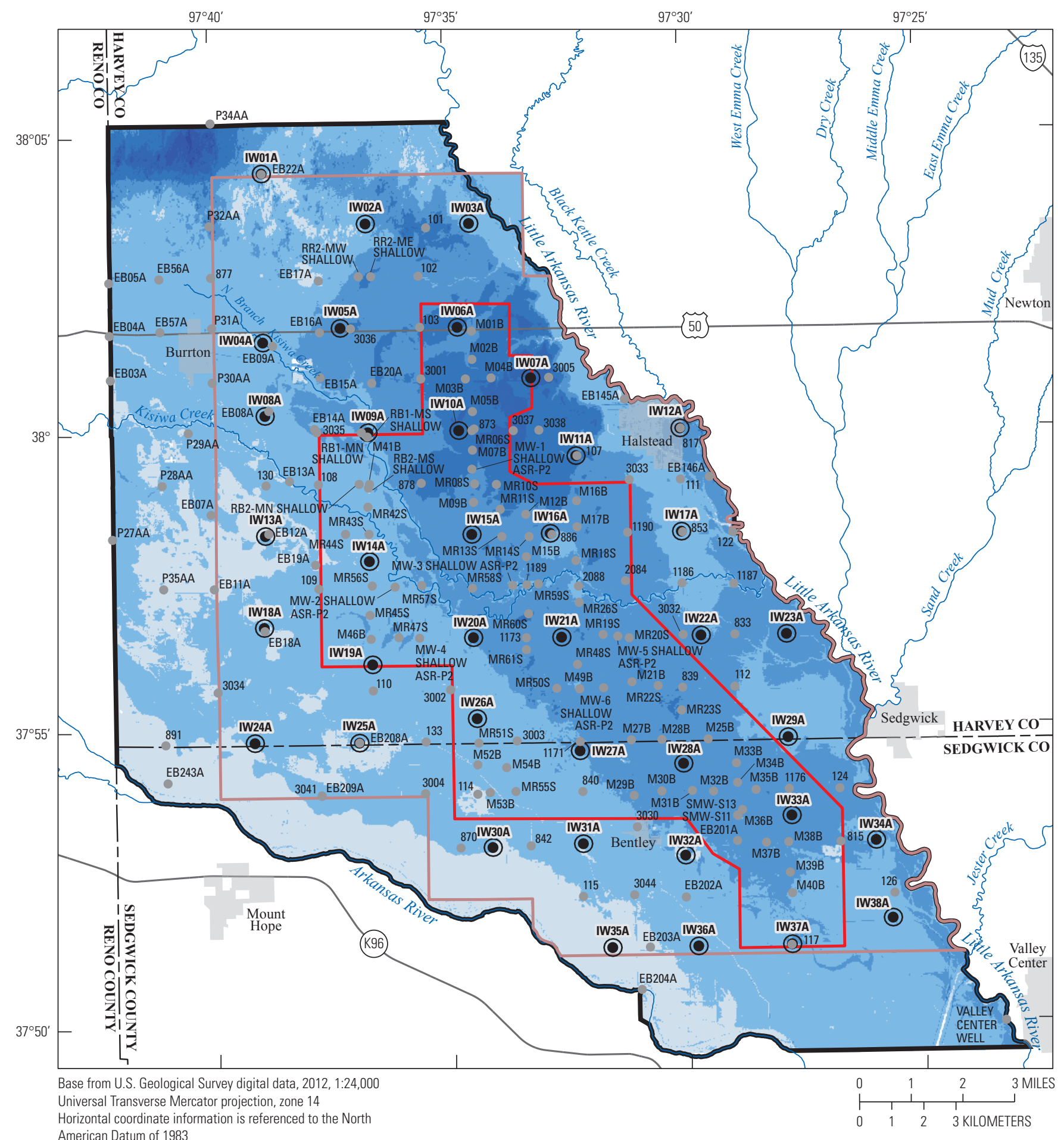

Horizontal coordinate information is referenced to the North American Datum of 1983

Figure 6. Depth to water in the shallow part of the Equus Beds aquifer, January 2015.
Depth to water Less than zero feet Zero to 10 feet 10 to 20 feet 20 to 30 feet 30 to 40 feet 40 to 50 feet 50 to 60 feet Greater than 60 feet

\section{EXPLANATION}

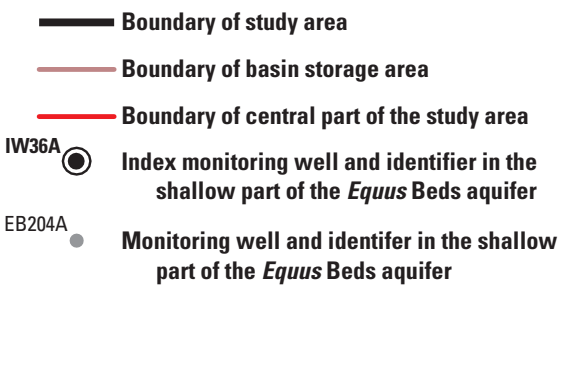




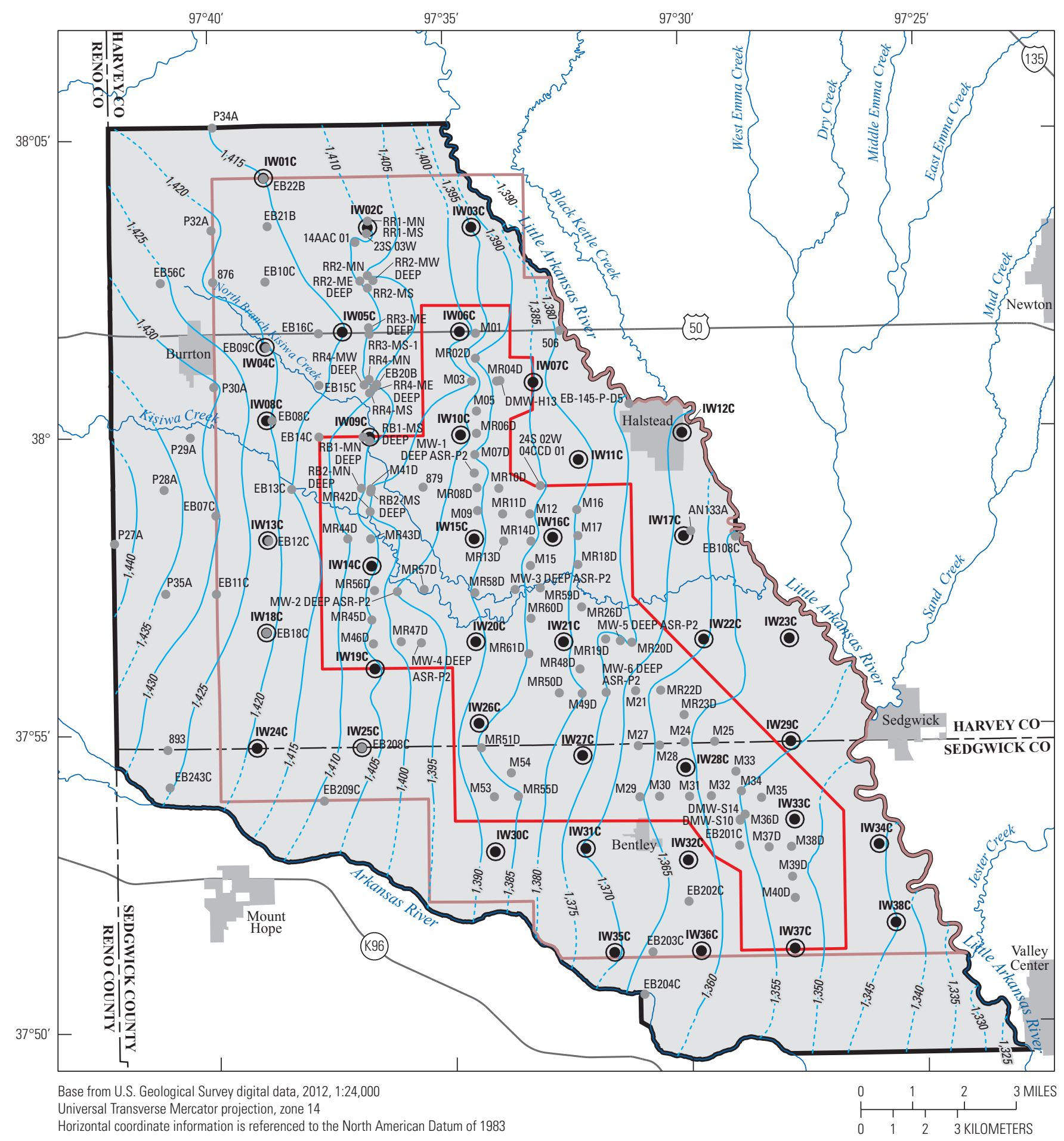

Horizontal coordinate information is referenced to the North American Datum of 1983

EXPLANATION

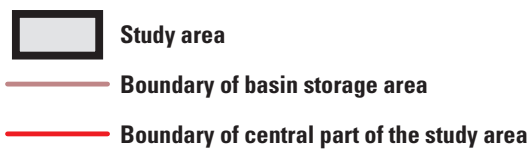
- 1,385 - Potentiometric contour - Shows altitude at which water level would have stood in tightly cased wells in the deep part of the Equus Beds aquifer, January 2015. Short dash where inferred. Contour interval 5 feet. Datum is North American Vertical Datum of 1988
(O) Index monitoring well and identifier in the deep part of the Equus beds aquifer EB204C
Monitoring well and identifier in the deep part of the Equus beds aquifer

Figure 7. Potentiometric surface of the deep part of the Equus Beds aquifer, January 2015. 


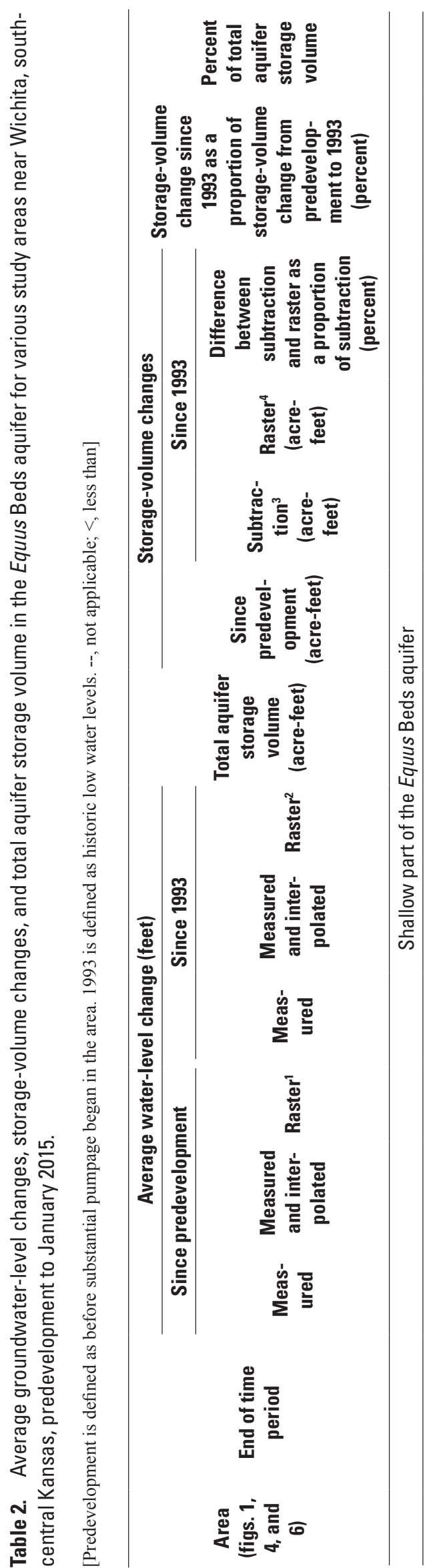

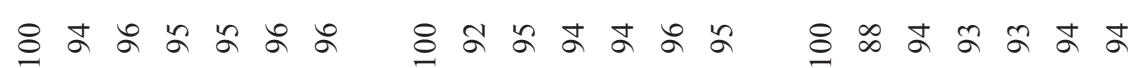
1:

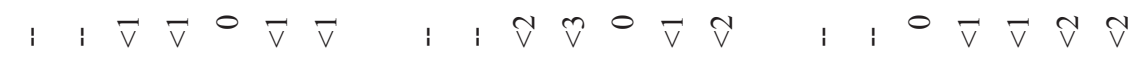

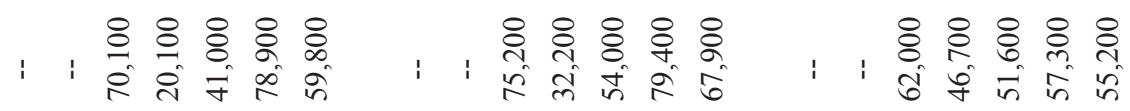

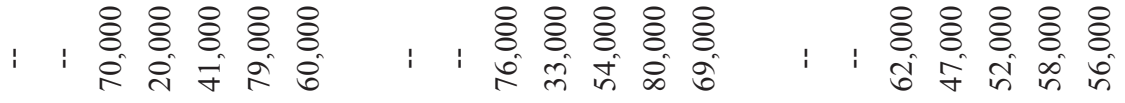

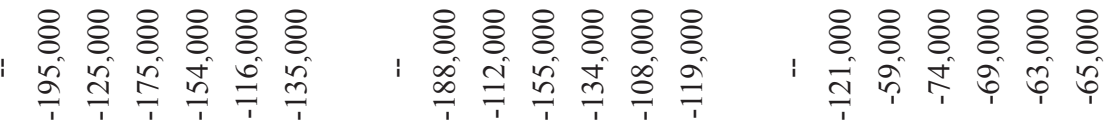

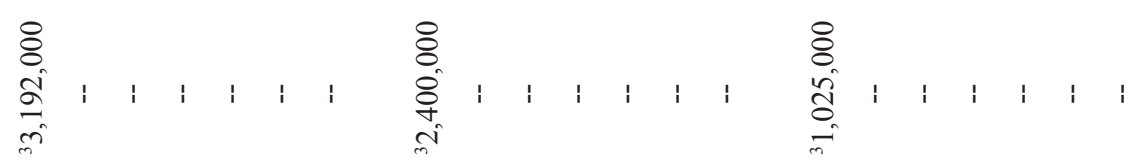

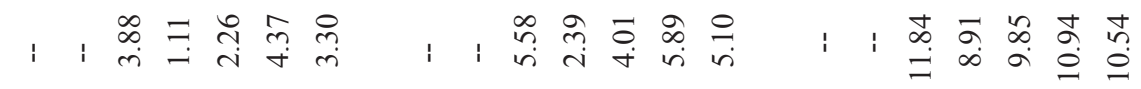

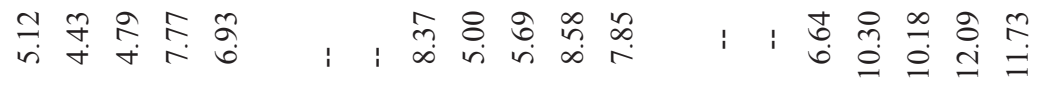

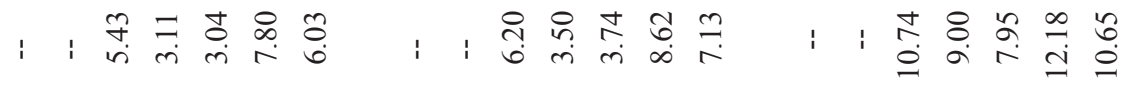

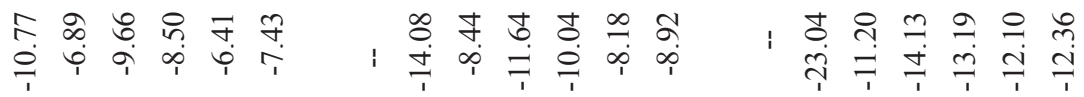

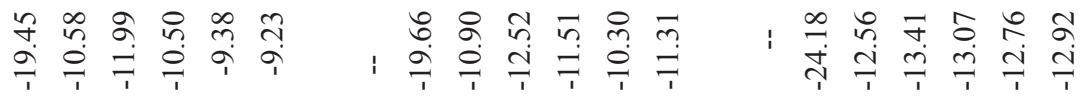

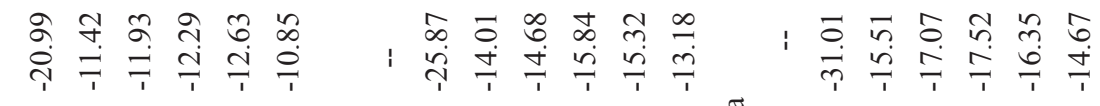

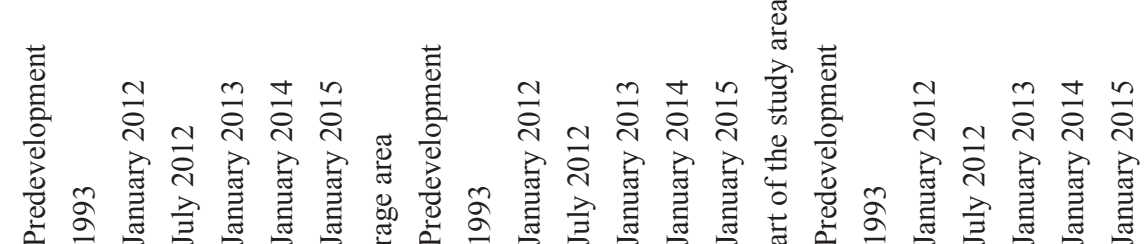

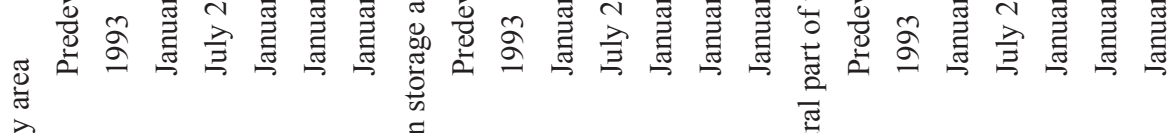
密 


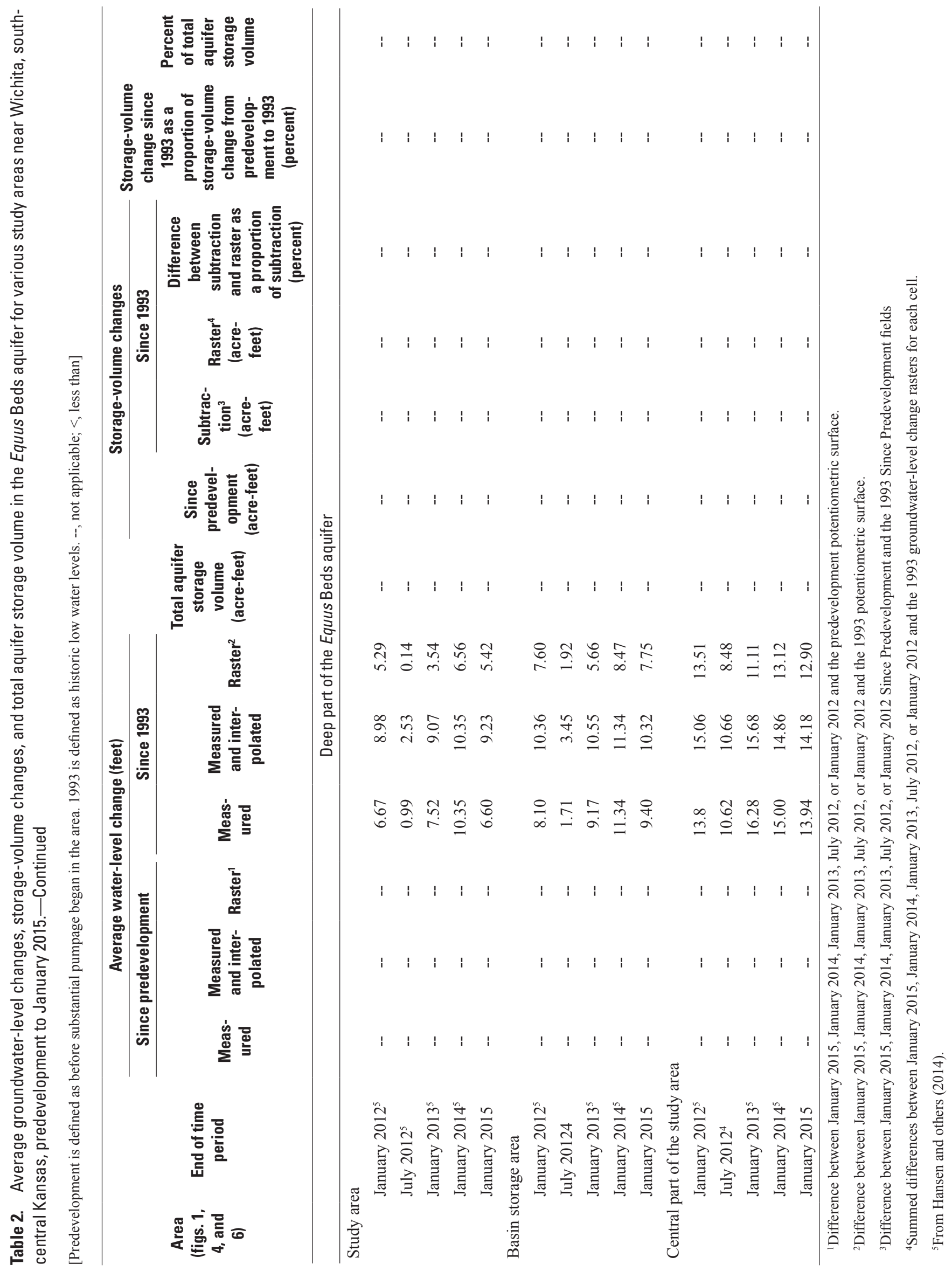




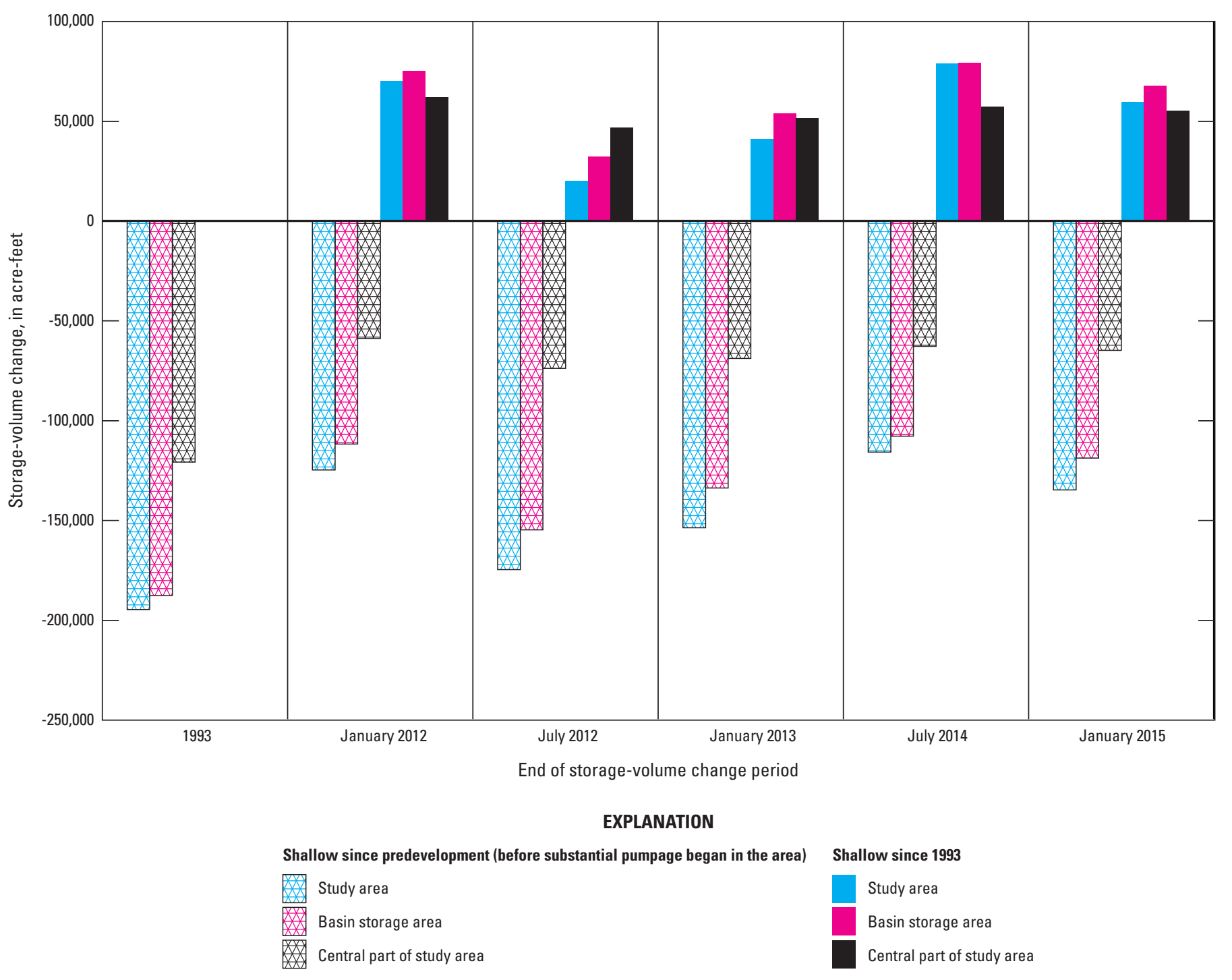

Figure 8. Storage-volume changes since predevelopment and since 1993 in the study area, the basin storage area, and the central part of the study area (modified from Hansen and others, 2014). 


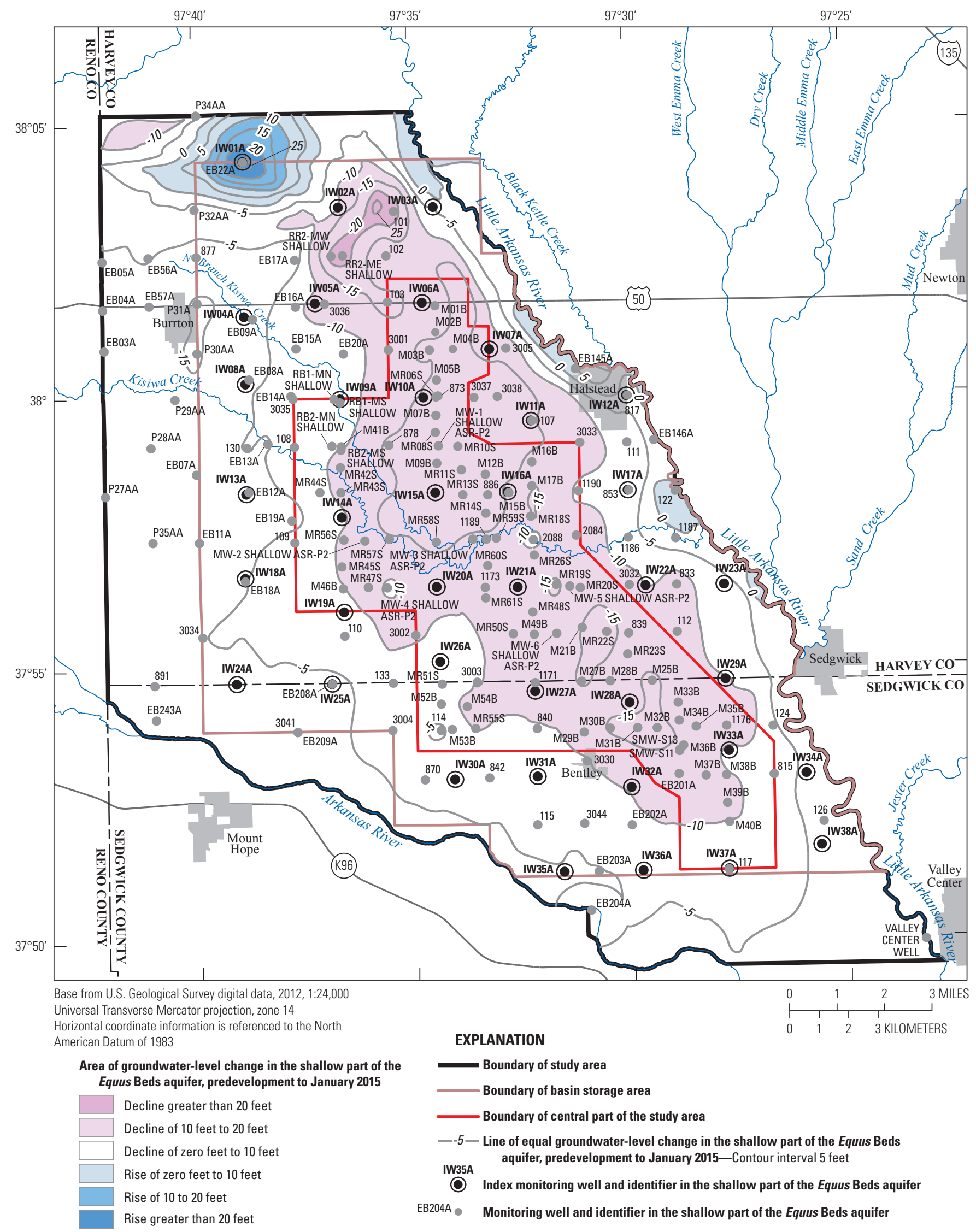

Figure 9. Groundwater-level changes in the shallow part of the Equus Beds aquifer, predevelopment to January 2015. 


\section{3 to January 2015}

Groundwater levels in the entire study area, with minor exceptions, rose or remained similar to groundwater levels in 1993 for the period from 1993 to January 2015 in the shallow part of the Equus Beds aquifer (fig. 10). Likewise, groundwater levels in the entire study area rose or remained similar to groundwater levels in 1993 for the period from 1993 to January 2015 in the deep part of the Equus Beds aquifer (fig. 11). Average groundwater-level rises from 1993 to January 2015 in the shallow and deep parts of the aquifer were greater in the central part of the study area than in either the basin storage area or the entire study area (table 2). Groundwater-level rises of greater than $10 \mathrm{ft}$ from 1993 to January 2015 covered most of the central part of the study area in the shallow and deep parts of the aquifer (figs. 10 and 11). Rises greater than $20 \mathrm{ft}$ in the shallow and deep parts of the aquifer mostly were within the north-central part of the study area (figs. 10 and 11). Groundwater levels declined at least $10 \mathrm{ft}$ near well IW02A and around well P32AA in the northwest part of the study area in the shallow part of the Equus Beds aquifer from 1993 to January 2015 (fig. 10). Declines in the study area were all less than $10 \mathrm{ft}$ in the deep part of the Equus Beds aquifer from 1993 to January 2015 (fig. 11). Rises in groundwater levels from 1993 to January 2015 in the central part of the study area in the shallow and deep parts of the aquifer were most likely the result of the city of Wichita adopting the ILWSP strategy in 1993 that decreased the amount of the city of Wichita's pumping from the Equus Beds aquifer in 2014 to the smallest amount since 1940 (figs. 2B and 3).

The increase in storage volume for the study area from 1993 to January 2015 was 59,800 acre-ft by the raster method (table 2). This increase was equivalent to about 2 percent of the total amount of aquifer storage volume in the study area $(3,192,000$ acre-ft) and a recovery of 31 percent of the storage volume previously lost from predevelopment (before substantial pumpage began in the area in September 1940) to 1993 $(195,000$ acre-ft) in the shallow part of the Equus Bed aquifer (table 2). Storage volume in the central part of the study area increased by about 55,200 acre-ft from 1993 to January 2015 (table 2). This increase was equivalent to about 5 percent of the total amount of aquifer storage volume in the central part of the study area (1,025,000 acre-ft; table 2). The 1993 to January 2015 recovery of storage volume previously lost from predevelopment to 1993 was about 46 percent (about 55,200 acre-ft) in the central part of the study area, which was a larger percentage recovery than in the basin storage area (37 percent or about 67,900 acre-ft) or the entire study area (31 percent or about 59,800 acre-ft; table 2). While much of the study area to the north, west, and south of the central part of the study area had groundwater-level declines from 1993 to January 2015, almost the entire central part of the study had rises (fig. 10). The lack of declines in the central part of the study area from 1993 to January 2015 could account for the larger percent of recovery of storage volume previously lost from predevelopment to 1993 in the central part of the study area. This larger percentage recovery of storage volume in the central part of the study area from 1993 to January 2015 was most likely the result of the city of Wichita adopting the ILWSP strategy to sustain the Equus Beds aquifer by reducing Wichita's pumpage from the aquifer, which in 2014 was the smallest amount since 1940 (fig. 2B). January 2015 storage volumes in the study area and the central part of the study area were about 96 percent $(3,057,000$ acre-ft) and 94 percent $(960,000$ acre-ft) of their respective total aquifer storage volumes (table 2). A more detailed numeric representation of the storage-volume changes is provided in table 2. Storagevolume changes since 1993 in the shallow part of the Equus Beds aquifer in the study area and the basin storage area have varied in the past few years (fig. 8, table 2). The central part of the study area decreased in storage volume from January 2012 to July 2012 and total variation has been within 11,000 acre-ft since (fig. 8, table 2).

\section{January 2014 to January 2015}

Between January 2014 and January 2015, groundwater levels in the shallow part of the Equus Beds aquifer mostly declined throughout the study area except in some areas in the northern, central, and southern parts of the study area (fig. 12). The central part of the study area had groundwater-level rises of about 3 feet in some places. The city of Wichita decreased its withdrawals by more than 50 percent in the central part of the study area from about 21,400 acre-ft in 2013 to about 9,700 acre-ft in 2014 (figs. 2B and 3; Kansas Geological Survey and Kansas Department of Agriculture, 2015). Other factors that could have affected the amount of water-level rises (and the amount of storage volume) in the central part of the study area are recharge from precipitation, artificial recharge, net groundwater flow into the area, and agricultural pumpage. Recharge commonly is positively correlated with precipitation; therefore recharge likely decreased in 2014 when precipitation was much less than average (fig. $2 A$ ). Artificial recharge did not change substantially from 2013 to 2014 (table 3). Net groundwater flow into the area may have decreased as indicated by an average groundwater-level change from January 2014 to January 2015 that was less for the central part of the study area $(-0.40 \mathrm{ft})$ than for the entire study area $(-1.07 \mathrm{ft}$; table 2, based on the raster method since 1993), which probably resulted in reducing the hydraulic gradient on the upgradient side of the central part of the study area and amount of groundwater flow into the central part of the study area, and increasing the gradient on the downgradient side and amount of groundwater flow out of the central part of the study area. Agricultural pumpage increased inside and outside the study area (figs. $2 B$ and 3; Kansas Geological Survey and Kansas Department of Agriculture, 2015). As a result, groundwaterlevels probably recovered less in the central part of the study area than anticipated from the decreased Wichita withdrawals because of decreased recharge, decreased net groundwater flow, and increased agricultural pumpage. 


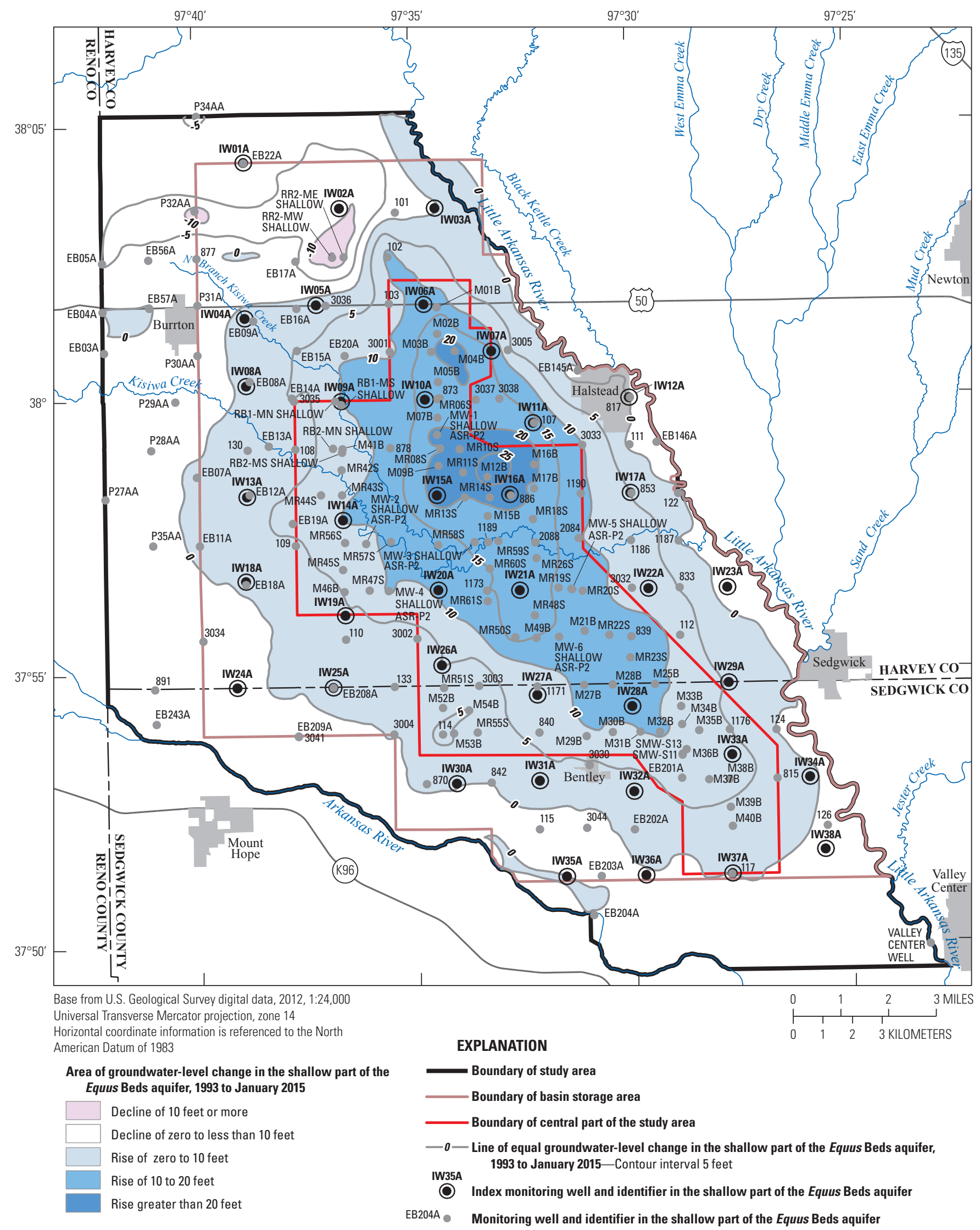

Figure 10. Groundwater-level changes in the shallow part of the Equus Beds aquifer, 1993 to January 2015. 


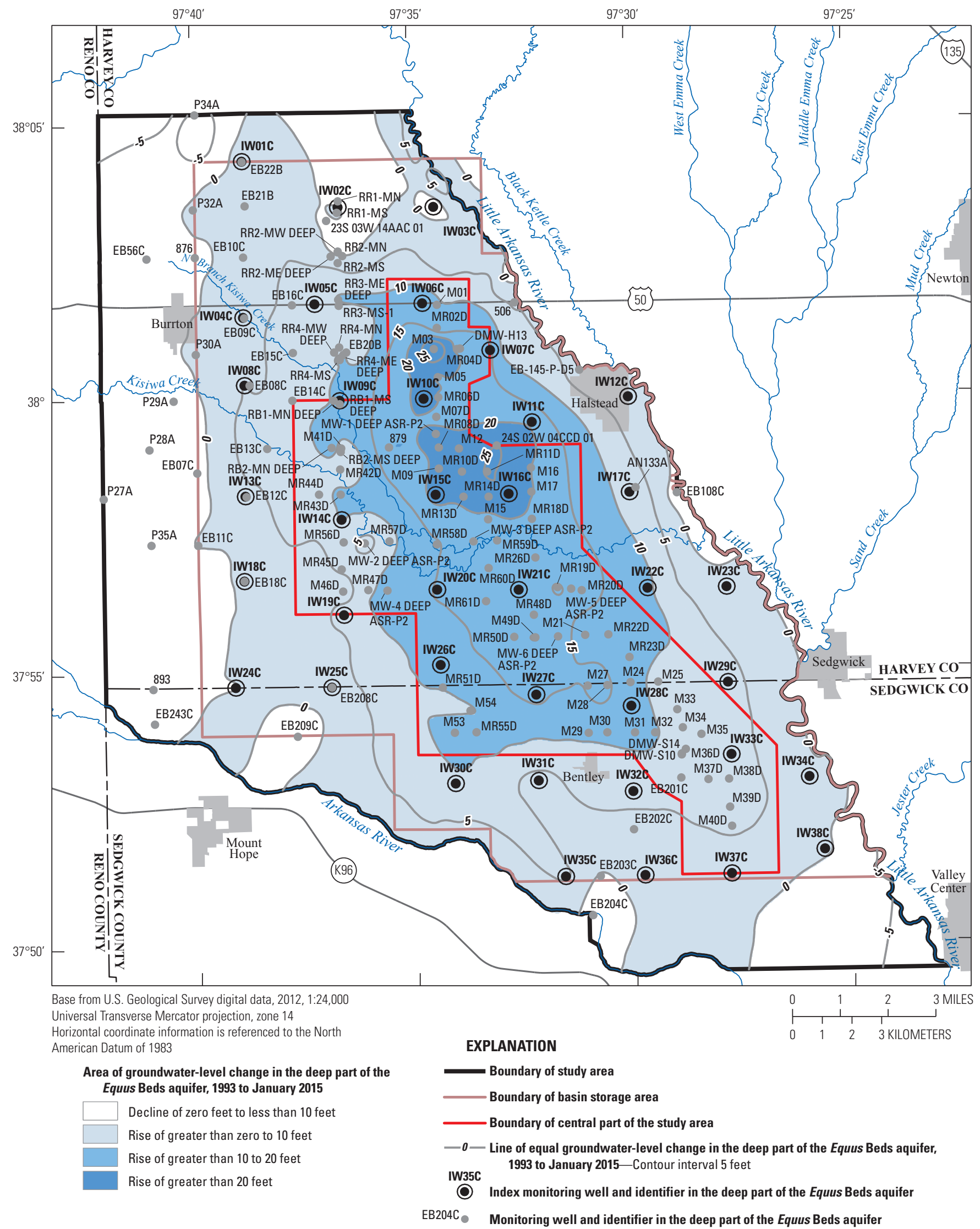

Figure 11. Groundwater-level changes in the deep part of the Equus Beds aquifer, 1993 to January 2015. 


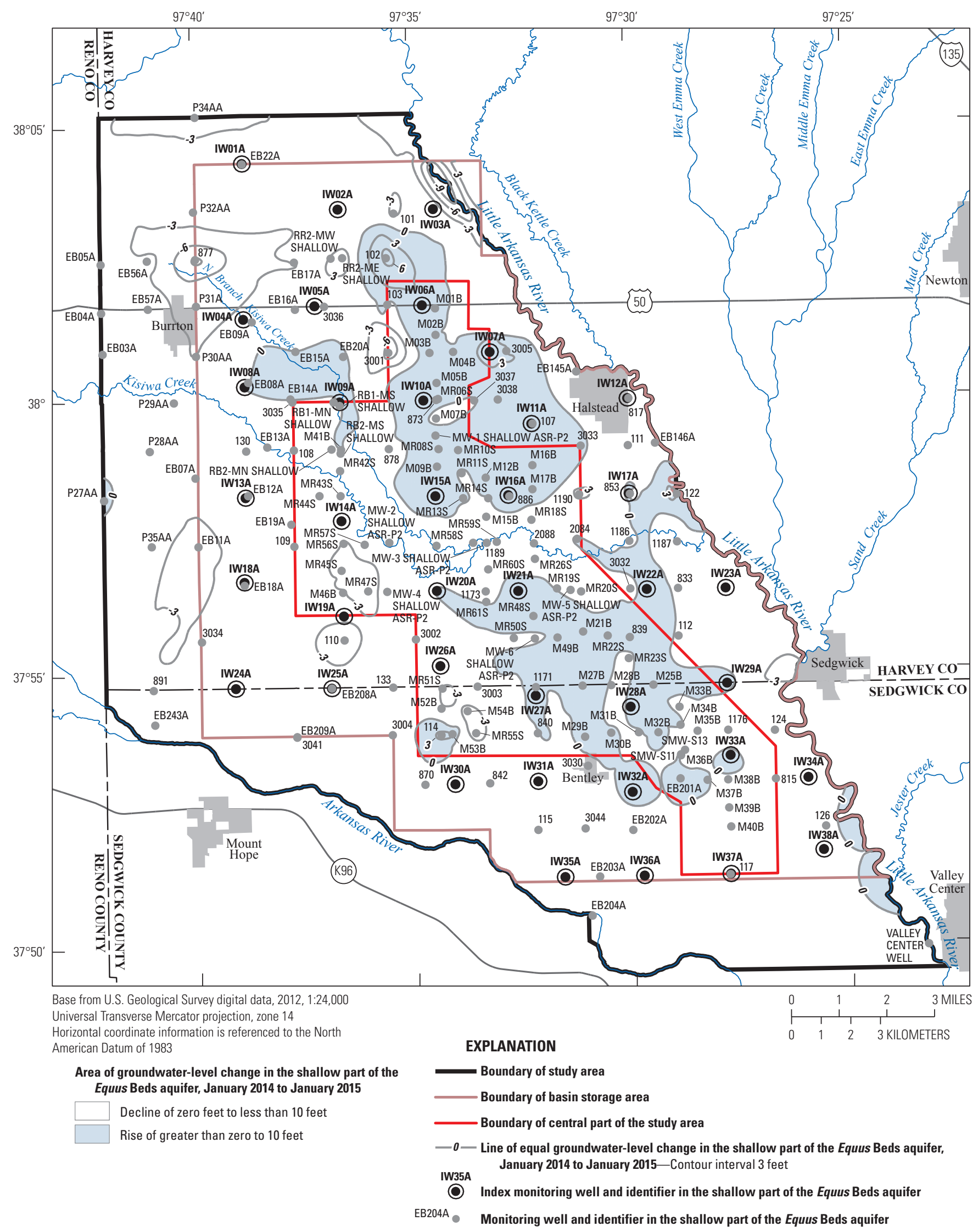

Figure 12. Groundwater-level changes in the shallow part of the Equus Beds aquifer, January 2014 to January 2015. 
A volumetric water budget can be used to calculate storage-volume change for the central part of the study area as the sum of recharge (artificial and from precipitation) and net groundwater flow minus the total groundwater pumpage from the area. Artificial recharge, recharge from precipitation, and net groundwater flow for the central part of the study area all decreased from 2013 to 2014 (table 3). Groundwater withdrawals through pumping also decreased (table 3 ) because Wichita decreased withdrawals from the aquifer by more than 50 percent (figs. $2 B$ and 3 ). The substantial decrease in total groundwater pumpage from 2013 to 2014 (about 10,412 acre- $\mathrm{ft}$ ) did not result in an increase in storage volume because it was offset by decreased recharge $(6,502$ acre- $\mathrm{ft})$ and an even greater decrease in net groundwater flow (11,710 acre-ft; table 3).

\section{Summary}

Development of the Wichita well field began in the 1940s in the Equus Beds aquifer to provide Wichita, the largest city in the State of Kansas, a new water-supply source. After development of the Wichita well field began, groundwater levels in the Equus Bed aquifer began to decline. Extensive development of irrigation wells began in the 1970s. Groundwater levels substantially declined in the Equus Beds aquifer because of city and irrigation withdrawals. Groundwater-level declines are likely to cause movement or increased movement of brine from past oil and gas production near Burrton, Kansas, and movement of natural saline water from the Arkansas River to the Wichita well field. Further movement of oil-field brine water from near Burrton, Kans., and saline water from the Arkansas River may limit use or require treatment of water from the aquifer for public supply and irrigation uses. Groundwater levels reached a historical minimum in 1993 because of drought conditions, irrigation, and city of Wichita withdrawals from the aquifer. This historical minimum in groundwater levels prompted Wichita to adopt the Integrated Local Water Supply Program (ILWSP) in 1993 to ensure that the city's water needs would be met through 2050 and beyond. A key component of the ILWSP is the Equus Beds Aquifer Storage and Recovery (ASR) project. The Equus Beds ASR project's goal is to store and eventually recover groundwater and help protect the aquifer from oil-field brine waters near Burrton, Kans., and saline water from the Arkansas River.

The previously published predevelopment potentiometric surface of the shallow part of the Equus Beds aquifer was revised because the value used for the predevelopment groundwater level at well P34AA was changed from the 1939 measurement to the April 1940 measurement. The main difference between the revised map and the previously published predevelopment map of the shallow part of the aquifer was in the northwestern part of the study area where the area of recharge was decreased in size and the hydraulic gradient increased toward well P34AA.

Groundwater mostly flowed from west to east in the shallow and deep parts of the Equus Beds aquifer in January 2015. The northwest part of the study area included an area of recharge in the shallow part of the Equus Beds aquifer. Average groundwater-level declines in the shallow part of the aquifer from predevelopment to January 2015 were greater in the central part of the study area than the entire study area. A large area of declines greater than $10 \mathrm{ft}$ in the shallow part of the aquifer covered most of the central part of the study area and extended beyond it.

Groundwater-level changes in the shallow part of the aquifer from predevelopment to January 2015 indicated declines greater than $10 \mathrm{ft}$ in the central part of the study area. Average groundwater-level rises from 1993 to January 2015 in the shallow and deep parts of the Equus Beds aquifer were greater in the central part of the study area than in the entire study area. Groundwater-level rises of greater than $10 \mathrm{ft}$ from 1993 to January 2015 covered most of the central part of the study area in the shallow and deep parts of the aquifer; groundwater-level rises greater than $20 \mathrm{ft}$ mostly were within the north-central part of the study area. Rises in groundwater levels from 1993 to 2015 in the central part of the study area in the shallow and deep parts of the aquifer were most likely the result of the adoption of the ILWSP strategy in 1993 by the city of Wichita, which decreased the amount of city pumpage

Table 3. Volumetric water budget in the central part of the study area, 2013 to 2014.

\begin{tabular}{|c|c|c|c|c|c|c|c|c|c|}
\hline Year & $\begin{array}{c}\text { Storage-volume } \\
\text { change } \\
\text { (acre-feet) }\end{array}$ & $=$ & $\begin{array}{l}\text { Recharge from } \\
\text { precipitation }{ }^{1} \\
\text { (acre-feet) }\end{array}$ & + & $\begin{array}{l}\text { Artificial recharge }{ }^{2} \\
\text { (acre-feet) }\end{array}$ & + & $\begin{array}{c}\text { Net groundwater } \\
\text { flow } \\
\text { (acre-feet) }\end{array}$ & - & $\begin{array}{l}\text { Total pumping }^{3} \\
\text { (acre-feet) }^{\text {(acre }}\end{array}$ \\
\hline 2013 & 5,700 & & 19,725 & & 1,122 & & 12,395 & & 27,542 \\
\hline 2014 & $-2,100$ & & 13,393 & & 952 & & 685 & & 17,130 \\
\hline
\end{tabular}

${ }^{1}$ Recharge from precipitation as defined here includes the effects of irrigation return flow and evapotranspiration. Recharge from precipitation estimated using the average proportion of precipitation that becomes recharge from Kelly and others (2013) (17 percent) multiplied by the actual annual precipitation total in feet (3.30 and 2.24 feet in 2013 and 2014, respectively) and the area of the central part of the study area (35,200 acres).

${ }^{2}$ Artificial recharge from U.S. Geological Survey (2015a).

${ }^{3}$ Total pumping from Kansas Geological Survey and Jim Bagley, Kansas Department of Agriculture, written commun., 2015. 
from the Equus Beds aquifer in 2014 to the smallest amount since 1940 .

The 1993 to January 2015 recovery of storage volume previously lost from predevelopment to 1993 was about 46 percent $(55,200$ acre-feet) in the central part of the study area, which was a larger percent recovery than in the basin storage area (37 percent or 67,900 acre-feet) or the entire study area (31 percent or 59,800 acre-feet). This larger percentage recovery of storage volume in the central part of the study area was most likely a result of Wichita adopting the ILWSP strategy to reduce the city pumpage from the Equus Beds aquifer. January 2015 storage volumes in the study area and the central part of the study were about 96 percent $(3,057,000$ acre-feet) and 94 percent $(960,000$ acre-feet) of their respective total aquifer storage volumes.

Between January 2014 and January 2015, the shallow part of the Equus Beds aquifer in the central part of the study area had groundwater-level rises of about 3 feet in some places, probably because Wichita decreased its withdrawals from the aquifer in 2014 by more than 50 percent. Groundwater-levels probably recovered less than anticipated from the decreased Wichita withdrawals because of decreased recharge, decreased net groundwater flow, and increased agricultural pumpage. A volumetric water budget for the central part of the study area between 2013 and 2014 showed that the 10,412 acre-feet decrease in total pumping did not result in an increase in storage volume because it was more than offset by a 6,502 acre-feet decrease in recharge (artificial and from precipitation) and a 11,710 acre-feet decrease in net groundwater flow.

\section{References Cited}

Aucott, W.R., Myers, N.C., and Dague, B.J., 1998, Status of ground-water levels and storage in the Wichita well field area, south-central Kansas, 1997: U.S. Geological Survey Water-Resources Investigations Report 98-4095, 15 p. [Also available at http://pubs.usgs.gov/wri/1998/4095/ report.pdf.]

City of Wichita, 2008, City of Wichita, KS meeting the demands of a growing community: Transformations, Alliance for Innovation newsletter, v. 2, no. 3, 6 p.

City of Wichita, 2013, Wichita area future water supplyA model program for other municipalities: Wichita, Kans., accessed July 9, 2013, at http:/www.wichita.gov/ Government/Departments/PWU/UtilitiesDocuments/ WICHITA\%20AREA\%20FUTURE\%20WATER\%20 SUPPLY.pdf.
Cunningham, W.L., and Schalk, C.W., comps., 2011, Groundwater technical procedures of the U.S. Geological Survey: U.S. Geological Survey Techniques and Methods, book 1, chap. A1, 151 p. [Also available at http://pubs.usgs.gov/ $\mathrm{tm} / 1 \mathrm{a} 1 /$.

Desilva, Viraj, and Ary, Deb, 2011, Aquifer storage and recovery program remedies Wichita's groundwater problems: Journal of the American Water Works Association, v. 103, no. 5, p. 94-99.

Esri, 2014a, ArcGIS help 10.2, 10.2.1, and 10.2.2-Contour (spatial analyst): Esri, accessed February 10, 2015, at http:// resources.arcgis.com/en/help/main/10.2/009z/009z00000 0ts000000.htm.

Esri, 2014b, ArcGIS help 10.2, 10.2.1, and 10.2.2-How topo to raster works: Esri, accessed February 10, 2015, at http:// resources.arcgis.com/en/help/main/10.2/009z/009z00000 07m000000.htm.

Esri, 2014c, ArcGIS help 10.2, 10.2.1, 10.2.2-An overview of the map algebra toolset: Esri, accessed February 10, 2015, at http://resources.arcgis.com/en/help/main/10.2/009z /009z000000z6000000.htm.

Esri, 2014d, ArcGIS help 10.2 - Zonal statistics (spatial analyst): Esri, accessed February 10, 2015, at http://resources. arcgis.com/en/help/main/10.2/009z/009z000000w7000000. htm.

Gibson, Campbell, 1998, Population of the 100 largest cities and other urban places in the United States - 1790-1990: Washington, U.S. Census Bureau, Population Division Working Paper no. 27, accessed January 10, 2010, at http://www.census.gov/population/www/documentation/ twps0027/twps0027.html.

Hansen, C.V., 2011, Status of groundwater levels and storagevolume in the Equus Beds aquifer near Wichita, Kansas, January 2011: U.S. Geological Survey Scientific Investigations Map 3192, 1 sheet, scale 1:84,480. [Also available at http://pubs.usgs.gov/sim/3192.]

Hansen, C.V., and Aucott, W.R., 2001, Status of ground-water levels and storage-volume in the Wichita well field area, south-central Kansas, 1998-2000: U.S. Geological Survey Water-Resources Investigations Report 00-4267, 27 p.

Hansen, C.V., Lanning-Rush, J.L., and Ziegler, A.C., 2013, Revised shallow and deep water-level and storage-volume changes in the Equus Beds aquifer near Wichita, Kansas, predevelopment to 1993: U.S. Geological Survey Scientific Investigations Report 2013-5170, 18 p. [Also available at http://dx.doi.org/10.3133/sir20135170.] 
Hansen, C.V., Whisnant, J.A., and Lanning-Rush, J.L., 2014, Status of groundwater levels and storage-volume in the Equus Beds aquifer near Wichita, Kansas, 2012 to 2014: U.S. Geological Survey Scientific Investigations Report 2014-5185, 39 p. [Also available at http://dx.doi. org/10.3133/sir20145185.]

Heath, R.C., 1983, Basic ground-water hydrology: U.S. Geological Survey Water Supply Paper 2220, 84 p. [Also available at http://pubs.er.usgs.gov/publication/wsp2220.]

Juracek, K.E., and Hansen, C.V., 1995, Digital maps of the extent, base, top, and 1991 potentiometric surface of the High Plains aquifer in Kansas: U.S. Geological Survey Open-File Report 95-758, scales 1:500,000 and $1: 1,000,000$.

Kansas Department of Agriculture, 2005, In the matter of the city of Wichita's applications to operate an aquifer storage and recovery project in Harvey and Sedgwick Counties, Kansas-Applications to appropriate water, file nos. 45,567; 45,$568 ; 45,569 ; 45,570 ; 45,571 ; 45,572 ; 45,573 ; 45,574$; 45,575; 45,576; and 46,081: Topeka, Kans., Kansas Department of Agriculture, Division of Water Resources, 21 p.

Kansas Geological Survey, 1992, Geology_Generalized surficial: Lawrence, Kans., Kansas Data Access and Support Center, accessed August 13, 2014, at http://www.kansasgis. org/catalog/index.cfm?data_id=255\&SH=geology?data_ id=255\&show_cat $=99$.

Kansas Geological Survey, 2015, WIZARD water well levels database: Kansas Geological Survey database, accessed January 23, 2014, at http://www.kgs.ku.edu/Magellan/ WaterLevels/index.html.

Kansas Geological Survey and Kansas Department of Agriculture, 2015, Water Information Management and Analysis System (WIMAS) for the Web: Kansas Department of Agriculture, Division of Water Resources database, accessed February 10, 2015, at http://hercules.kgs.ku.edu/geohydro/ wimas/index.cfm.

Kelly, B.P., Pickett, L.L., Hansen, C.V., and Ziegler, A.C., 2013, Simulation of groundwater flow, effects of artificial recharge, and storage-volume changes in the Equus Beds aquifer near the city of Wichita, Kansas well field, 19392008: U.S. Geological Survey Scientific Investigations Report 2013-5042, 90 p. [Also available at http://pubs. er.usgs.gov/publication/sir20135042.]

Klager, B.J., Kelly, B.P., and Ziegler, A.C., 2014, Preliminary simulation of chloride transport in the Equus Beds aquifer and simulated effects of well pumping and artificial recharge on groundwater flow and chloride transport near the city of Wichita, Kansas, 1990 through 2008: U.S. Geological Survey Open-File Report 2014-1162, 76 p., http:// dx.doi.org/10.3133/ofr20141162.
Lane, C.W., and Miller, D.E., 1965, Geohydrology of Sedgwick County, Kansas: Kansas Geological Survey Bulletin 176, 100 p. [Also available at http://www.kgs.ku.edu/ General/Geology/Sedgwick/index.html.]

Lohman, S.W., 1972, Definitions of selected ground-water terms-Revisions and conceptual refinements: U.S. Geological Survey Water-Supply Paper 1988, 21 p. [Also available at http://pubs.usgs.gov/wsp/wsp_1988/.]

Myers, N.C., Hargadine, G.D., and Gillespie, J.B., 1996, Hydrologic and chemical interaction of the Arkansas River and the Equus Beds aquifer between Hutchinson and Wichita, south-central Kansas: U.S. Geological Survey WaterResources Investigations Report 95-4191, 100 p. [Also available at http://pubs.er.usgs.gov/publication/wri954191.]

National Oceanic and Atmospheric Administration, 2015, Daily/monthly normals for Wichita Airport, KS: National Oceanic and Atmospheric Administration Online Weather Data, accessed January 20 2015, at http://www.nws.noaa. gov/climate/xmacis.php?wfo=ict.

Spinazola, J.M., Gillespie, J.B., and Hart, R.J., 1985, Groundwater flow and solute transport in the Equus beds area, south-central Kansas: U.S. Geological Survey WaterResources Investigations Report 85-4336, 68 p. [Also available at http://pubs.er.usgs.gov/publication/wri854336.]

Stramel, G.J., 1956, Progress report on the ground-water hydrology of the Equus beds area, Kansas: Kansas Geological Survey Bulletin 119, pt. 1, 59 p.

Stramel, G.J., 1967, Progress report on the ground-water hydrology of the Equus beds area, Kansas 1966: Kansas Geological Survey Bulletin 187, pt. 2, 27 p.

Stullken, L.E., Watts, K.R., and Lindgren, R.J., 1985, Geohydrology of the High Plains aquifer, western Kansas: U.S. Geological Survey Water-Resources Investigations Report 85-4198, 86 p. [Also available at http://pubs.er.usgs.gov/ publication/wri854198.]

Tappa, D.J., Lanning-Rush, J.L., Klager, B.J., Hansen, C.V., and Ziegler, A.C., 2015, Water quality of the Little Arkansas River and Equus Beds Aquifer before and concurrent with large-scale artificial recharge, south-central Kansas, 1995-2012 (ver. 1.1, May 6, 2015): U.S. Geological Survey Scientific Investigations Report 2015-5023, 67 p. [Also available at http://dx.doi.org/10.3133/sir20155023.]

U.S. Census Bureau, 2012, Intercensal estimates of the resident population for incorporated places and minor civil division-April 1, 2000 to July 1, 2010: U.S. Census Bureau, Population Division, SUB-EST00INT-TOT, accessed July 9, 2013, at http:/www.census.gov/popest/ data/intercensal/cities/cities2010.html. 
U.S. Geological Survey, 2015a, Equus Beds Water Recharge: U.S. Geological Survey Web page, accessed August 11, 2015, at http://ks.water.usgs.gov/water-recharge.

U.S. Geological Survey, 2015b, National Water Information System-Web interface-USGS water data for Kansas: U.S. Geological Survey database, accessed February 9, 2015, at http://waterdata.usgs.gov/ks/nwis/.

Warren, D.R., Blain, G.T., Shorney, F.L., and Klein, L.J., 1995, IRP - A case study from Kansas: Journal of the American Water Works Association, v. 87, no. 6, p. 57-71.

Whittemore, D.O., 2007, Fate and identification of oil-brine contamination in different hydrogeologic settings: Applied Geochemistry, v. 22, no. 10, p. 2099-2114.

Whittemore, D.O., 2012, Distribution and change in salinity in the Equus Beds Aquifer in the Burrton Intensive Groundwater Use Control Area: Kansas Geological Survey Open-File Report 2012-1, 35 p.

Wichita Water Department, [1959?], 1958 annual report: Wichita, Kans., 8 p.

Williams, C.C., and Lohman, S.W., 1949, Geology and ground-water resources of a part of south-central Kansas, with special reference to the Wichita municipal water supply: Kansas Geological Survey Bulletin 79, 455 p.

Ziegler, A.C., Hansen, C.V., and Finn, D.A., 2010, Water quality in the Equus Beds aquifer and the Little Arkansas River before implementation of large-scale artificial recharge, south-central Kansas, 1995-2005: U.S. Geological Survey Scientific Investigations Report 2010-5023, 143 p. [Also available at http://pubs.usgs.gov/sir/2010/5023/.] 


\section{Appendix 1}

Table 1-1. Measured and interpolated water-level altitudes, water-level types, and measurement dates of wells in the Equus Beds aquifer, predevelopment, 1993, and January 2015. Available online at http://dx.doi.org/10.3133/sir20155121. 
Publishing support provided by: Rolla Publishing Service Center

For additional information concerning this publication, contact: Director, USGS Kansas Water Science Center

4821 Quail Crest Place

Lawrence, KS 66049

(785) 842-9909

Or visit the Kansas Water Science Center Web site at: http://ks.water.usgs.gov 



\section{$\frac{\mathbb{2}}{\mathrm{C}}$}

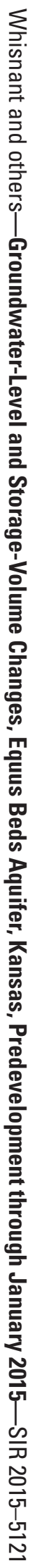

